\title{
THE LAW SOCIETY OF UPPER CANADA AND ACCESS TO JUSTICE: LESSONS FROM LAWYER-LICENSING REFORM
}

\section{David Wiseman*}

The process for licensing new lawyers in Ontario is in the midst of significant change following the Law Society of Upper Canada's approval of a recommendation by it's Articling Task Force to introduce of a 3year pilot project that will provide a program of practical legal training as an alternative to articling. This article describes and critically analyzes these changes and the process that led to them in relation to three aspects of access to justice: access to the legal profession, access to legal services, and access to legal governance. The analysis reveals numerous shortcomings that provide lessons that could be applied to the proposal for evaluating the pilot project as well as to the Law Society's recently announced initiative to overhaul its institutional approach to access to justice.

Le processus d'accès à la profession qui s'applique aux nouveaux avocats en Ontario fait actuellement l'objet de changements importants. Le Barreau du Haut-Canada a approuvé un projet pilote de trois ans recommandé par son Groupe de travail sur le stage, dans le cadre duquel il sera possible de suivre un programme de pratique du droit plutôt que de faire un stage. Le présent article décrit et analyse de façon critique ces changements - ainsi que le processus ayant mené aux changements - par rapport à trois aspects de l'accès à la justice : l'accès à la profession juridique, l'accès aux services juridiques et l'accès à la gouvernance juridique. L'analyse fait ressortir de nombreuses lacunes qui pourraient servir de leçons à appliquer à la proposition d'évaluation du projet pilote ainsi qu'à l'initiative récemment annoncée du Barreau visant à réviser son approche institutionnelle à l'accès à la justice.

\section{INTRODUCTION}

The process for licensing new lawyers in Ontario is in the midst of significant change with the introduction of a 3-year pilot project that will provide a program of practical legal training as an alternative to articling. The Law Society of Upper Canada (the "Law Society") ${ }^{1}$ decided to introduce the practical legal training program option following a recommendation from the Articling Task Force that it established in 2011. ${ }^{2}$ The Law Society packaged the changes to lawyer-licensing as offering alternative 'Pathways' to admission for new lawyers. One pathway is the practical legal training program, officially known as the Law Practice Program (LPP). The other pathway is the Articling Program, which has simultaneously been reformed with the introduction of a more robust and

Faculty of Law, Common Law (English) Section, University of Ottawa. Some of the content of this article is based upon a submission to the Articling Task Force by a group of which I was part: the University of Ottawa, Faculty of Law, Adhoc Working Group on Articling and Access to Justice. The other members of the ad-hoc working group were: Adam Dodek (Professor), Suzanne Bouclin (Professor), Chantal Morton (Adjunct Professor), Lisa Blair (Assistant Dean, Student Services), Chelsea Paradis (Social Justice Careers Counselor, Student Services), Mikaila Greene (student), Ziad Yehia (student). Thanks to Jessica Stansfield for research assistance (and to the Law Foundation of Ontario for funding her position). Thanks also to my colleague Amy Salyzyn and the two anonymous reviewers for valuable comments.

1 The Law Society is the legislatively mandated self-regulatory organization that governs lawyers in Ontario and, since 2007, paralegals (who have a different licensing process).

2 The Articling Task Force was created in late June, 2013, see Law Society of Upper Canada, Treasurer's Report to Convocation, (June 23, 2011) at 2 online: LSUC <http://www.lsuc.on.ca/WorkArea/DownloadAsset.aspx?id=21474$85340>$ [LSUC, Treasurer's Report] 
systematized quality assurance system. Both pathways will be evaluated at the end of the 3-year pilot project and decisions will be made about the more permanent future of lawyer licensing in Ontario.

This article is about the extent to which access to justice was considered during the Law Society's process of devising the changes to lawyer licensing, as well as to what extent access to justice may be advanced by the changes wrought. In announcing the establishment of the Articling Task Force, the then Treasurer of the Law Society, Laurie Paulitza, stated that "[a]rticling must be a bridge, not a barrier, to candidates interested in being legal professionals and in responding to the needs of the public in Ontario." 3 This statement suggested that access to justice might have played a prominent role in the process of reviewing articling and lawyer licensing. However, in my analysis, the consideration given to access to justice issues by the Law Society and its Articling Task Force had a number of shortcomings. The resultant Pathways reforms may have reconstructed the lawyer licensing bridge, but the route to access to justice still has roadblocks.

Three aspects of access to justice relevant to the Law Society's efforts are examined: first, access to justice as 'access to the legal profession' for would-be lawyers; second, access to justice as 'access to legal services' for people in Ontario with so-called 'everyday legal problems'; and, third, access to justice as 'access to legal governance' for the individuals and groups (and their rights and interests) who lack access to the legal profession or access to legal services. The upshot of my analysis is that the consideration given to the issues of access to the legal profession and access to legal services needed significant improvement, although the former was given more meaningful attention than the latter. This leads to the argument that the Law Society's process also suffered from a lack of access to legal governance. In my view, and as I discuss, these shortcomings provide lessons that ought to inform both the Law Society's plan for evaluation of the Pathways project and its newly announced initiative to revamp its institutional approach to access to justice. ${ }^{4}$ Those lessons are important not only for the future of lawyer licensing in Ontario but also to other significant issues about the regulation of the legal profession that the Law Society is grappling with on the more immediate horizon, such as whether to allow the use of so-called 'alternative business structures' for the delivery of legal services. ${ }^{5}$

This article proceeds in 3 parts. In Part 1, I frame the analysis by identifying the statutory duty of the Law Society in relation to access to justice and then briefly outline a conception of access to justice that can ground the three aspects that will be addressed. In Part 2, I explain the context, process and outcomes of the Law Society's and the Articling Task Force's review of lawyer licensing. In Part 3, I begin by identifying four problems with the manifestation of access to justice issues in the process and

3 As quoted in Law Society of Upper Canada, "Task force to address articling requirement", Ontario Lawyers Gazette (Summer 2011) 13 at 13.

4 The specific Pathways Project Evaluation Plan was approved in early 2014, see Law Society of Upper Canada, Professional Development and Competence Committee Report to Convocation, (27 February, 2014) at Tab 6.2 (para 5) [LSUC, Professional Development (February)]. The more general plan has begun with the recent launch of a new organizational initiative on access to justice, involving both internal and external aspects, intended to equip the Law Society to more effectively carry out its statutory duty to facilitate access to justice, see Law Society of Upper Canada, Report of the Treasurer's Advisory Group on Access to Justice Working Group, (February 27, 2014) online: LSUC $<\mathrm{http}$ //www.lsuc.on.ca/uploadedFiles/For_the Public/About the_Law_Society/Convocation_Decisions/2013/convjan20 14 treasurersadvisorygroup.pdf.> [LSUC, ${ }^{-}$TAG Working Group Report $]$.

5 On the issue of alternative business structures, see generally Richard Devlin \& Ora Morison, "Access to Justice and the Ethics and Politics of Alternative Business Structures" (2014) 91:3 Can Bar Rev 483. 
outcomes of the Articling Task Force and then address each in turn. This culminates in a consideration of the proposed plan for evaluation of the Pathways pilot project and the new initiative on access to justice.

\section{ACCESS TO JUSTICE AND THE LAW SOCIETY}

Two threshold questions need to be addressed to lay the foundation for assessing the consideration given to access to justice issues by the Law Society and the Articling Taskforce. The first question is: whether access to justice ought to have been considered at all? This can be answered by reference to the statutory duties set out in the Law Society's governing legislation - the Law Society Act (the Act). ${ }^{6}$ Since 2006, the Act has specified a number of principles that the Law Society is to apply in performing its functions and powers. ${ }^{7}$ These principles include a "duty to act so as to facilitate access to justice for the people of Ontario." ${ }^{8}$ Given this duty, the Law Society, in establishing the Articling Task Force, and the Articling Task Force itself in carrying out its work, would seem to have been duty-bound to consider the relationship between articling and access to justice. ${ }^{9}$

However, access to justice remains a contested concept and has been defined in various ways with varying scope. ${ }^{10}$ Therefore, a second threshold question is: what conception of access to justice should be considered? For present purposes, I will posit the conception of access to justice elaborated by Professor Roderick Macdonald in a study commissioned by the Law Society in the early 2000s as part of a broader project to inform itself in relation to its future governance activities. ${ }^{11}$

As Macdonald explains, traditionally, access to justice was regarded as focusing on access to legal counsel for court-based dispute resolution. ${ }^{12}$ But this understanding expanded over a number of decades

RSO 1990, c L8.

7 The functions of the Law Society are set out in s 4.1 of the Act. Ibid at s 4.1 .

$8 \quad$ Ibid at s.4.2.

$9 \quad$ It should be mentioned that the Society's duty in this regard might be heightened by the guarantee of equality in section 15 of the Canadian Charter of Rights and Freedoms. Canadian Charter of Rights and Freedoms, Part 1 of the Constitution Act, 1982, being Schedule B to the Canada Act 1982 (UK), 1982, c 11. That the Charter applies to the regulatory work of the Society is well established (Andrews v Law Society of British Columbia, [1989] 1 SCR 143).

10 See, for example: Mauro Cappelletti \& Bryant Garth, "Access to Justice: The Newest Wave in the Worldwide Movement to Make Rights Effective" (1978) 27 Buff L Rev 181; Allan C. Hutchinson, ed., Access To Civil Justice (Toronto; Carswell, 1990); William Conklin, "Whither Justice? The Common Problematic of Five Models of "Access to Justice", (2001) 19 Windsor YB Access Just 297; Roderick Macdonald, “Access to justice and law reform" (2001) 19 Windsor YB Access Just 317; Patricia Hughes, "Law Commissions and Access to Justice: what justice should we be talking about?" (2008) 46 Osgoode Hall LJ 773.

11 Roderick Macdonald, "Access to Justice in Canada Today: Scope, Scale and Ambitions" in Julia Bass, William A Bogart \& Frederick H Zemans, eds, Access to Justice for a New Century - The Way Forward (Toronto: Law Society of Upper Canada, 2005). The broader project is partly described by the editors in the Introduction to this book and Macdonald's analysis is the first paper in that publication, although this is only part of the full study of access to justice completed by Macdonald for the Law Society (the full study has never been made public).

12 A modernized version of this traditional focus was formulated in the following terms by the British Columbia Court of Appeal: "[Access to justice means] ... reasonable and effective access to courts of law and the opportunity to obtain legal services from qualified professionals, that are related to the determination and interpretation of legal rights and obligations by courts of law or other independent tribunals." See Christie v British Columbia (Attorney General), 2005 
to encompass more and more dispute resolution and justice-defining processes and institutions. By the time of the study, in Macdonald's analysis, the justice system was recognized to encompass "every institution where law is debated, created, found, organized, administered, interpreted and applied."13 Across this system, and in each institution and its associated activities, the ideal of access to justice imposes procedural, substantive and symbolic obligations. Procedurally, all people must have an equal right to adequately participate in the institution. Substantively, the outcomes of the various institutional activities must accord with an appropriate substantive conception of justice (although which conception is appropriate will often be contested). Symbolically, each institution and the system as a whole must provide adequate respect and recognition to all people - ultimately, this symbolic aspect seeks to ensure respect for the justice system and confidence in its outcomes. ${ }^{14}$ Macdonald argues that the barriers to procedural, substantive and symbolic access to justice can take a variety of forms - objective, subjective and sociological/psychological. ${ }^{15}$ Objective barriers exist in defects in the design and operation of the institutions, such as costs of participation and location of forums. Subjective barriers arise from individual and group disadvantages and inequalities suffered by people needing justice, such as lack of income or low literacy. Sociological and psychological barriers result from the individual and group impacts of social exclusion and alienation, which may produce an unwillingness to engage the justice system. $^{16}$

The breadth of Macdonald's definition enables it to include the three aspects of access to justice that are the concern of this article. First, access to legal services, including advice from and representation by a lawyer, is recognized by Macdonald as an issue of continuing importance, even though it is also now widely recognized that there are a variety of other means, beyond the traditional role of lawyers, by which people can and should be supported in seeking justice. ${ }^{17}$ The issue of access to legal services is of particular significance to people in Ontario with so-called 'everyday legal problems' (a term that will be unpacked in section 3.C.i., below). Second, access to the legal profession is, for Macdonald, identified as part of an obligation to promote legal empowerment for disenfranchised and under-empowered groups within law-making institutions. ${ }^{18}$ The legal profession plays an integral part in all manner of justice-related institutions and, in turn, influences the extent to which procedural, substantive and symbolic access to justice are attainable. This provides an instrumental basis for requiring access to the legal profession. This requirement is then bolstered by more direct considerations of substantive justice, such as the generally accepted norm of non-discrimination and the guarantee of equality in the Canadian

BCCA 631, [2006] 2 WWR 610 at 638 (as quoted in Kerri Froc, "Is the Rule of Law the Golden Rule? Accessing

'Justice' for Canada's Poor”' (2008) 87 Can Bar Rev 459 at 460 n 5)

13 Macdonald, supra note 11 at 23.

14 Ibid at 104-7.

15 Macdonald, supra note 11 at 26-9.

16 At the same time, Macdonald expresses reservations about the 'barriers' metaphor (Ibid at 29) and others have raised concerns about the categories of barriers (see, for instance, I Morrison \& J Mosher, "Barriers to Access to Civil Justice for Disadvantaged Groups" in Ontario Law Reform Commission, Rethinking Civil Justice: Research Studies for the Civil justice Review (Toronto: Ontario Law Reform Commission, 1996) Vol 2 at 645.

17 Others means are identified by Macdonald, supra note 11) and, more recently, in Canadian Bar Association, Reaching Equal Justice: An Invitation to Envision and Act (Ottawa: Canadian Bar Association, 2013).

18 Macdonald, supra note 11 at 92-3. 
Charter of Rights and Freedoms. ${ }^{19}$ Third, access to legal governance can also be regarded as arising from the obligation to ensure access to justice in law-making institutions. The Law Society, in carrying out its profession-governing function, is itself a delegated law-making institution and, in Macdonald's analysis, such institutions come within the obligation to ensure procedural, substantive and symbolic access to justice in their activities. ${ }^{20}$ For the purposes of this article, I will focus on two particular dimensions of the legal governance activities of the Law Society with respect to lawyer licensing: the extent to which concerns about access to legal services and access to the legal profession were able to be put before the Articling Task Force (a procedural dimension); and, the extent to which the Law Society and Articling Task Force gave sufficient normative weight to those concerns (a more substantive dimension).

The three aspects of access to justice against which this article measures the Law Society's reforms of lawyer licensing can thus be grounded in Macdonald's analysis of the contemporary understanding of the concept of access to justice. For present purposes, the reasonableness of this measure rests on the fact that Macdonald's study was undertaken for the Law Society itself. ${ }^{21}$

\section{THE LAW SOCIETY AND THE ARTICLING TASK FORCE: CONTEXT, PROCESS, OUTCOMES}

The immediate impetus for the formation of the Law Society's Articling Task Force in June 2011 was a concern within the organization about a shortage of articling positions in Ontario. ${ }^{22}$ At that time, most candidates for licensing as new lawyers in Ontario had to complete a three part training program as transition from the academic study of law. ${ }^{23}$ One part was passing two self-study examinations; the second part was articling, which consisted in a ten month period of work in a legal practice setting under

19 Supra note 9 at s 15 . See also sources in supra note 10.

20 Macdonald, supra note 11, at 88-9.

21 By the same token, there are other perspectives that examine the relationship between professional licensing regimes in general, such as articling, and access to justice that will not be considered in this article. In particular, the tools of economic analysis and consumer welfare perspectives have been used to assess the impact that professional licensing has on entry to the Canadian legal profession and the costs of legal services. See Michael Trebilcock "Regulating the Market for Legal Services," (2008) 45 Alta L Rev 215; Noel Semple “Access to Justice: Is Legal Services Regulation Blocking the Path?" (2013) 20:3 International Journal of the Legal Profession; and Noel Semple, "Access to Justice through Regulatory Reform" (6 July 2012), online: SSRN <http://ssrn.com/abstract=2101831>. For analyses in a US context, see: Gillian Hadfield, "The Price of Law: How the Market for Lawyers Distorts the Justice System," (2000) 98 Mich L Rev 953; Gillian Hadfield, "Legal Barriers to Innovation: The Growing Economic Cost of Professional Control Over Corporate Legal Markets," (2008) 60 Stan L Rev 1689; and, Clifford Winston, Robert W Crandall \& Vikram Maheshri, First Thing We Do, Let's Deregulate All the Lawyers (Washington: Brookings Institution Press, 2011).

22 Law Society of Upper Canada, Treasurer's Report to Convocation, (June 23, 2011) at 2 online: LSUC http://www.lsuc.on.ca/WorkArea/DownloadAsset.aspx?id=2147485340 > [LSUC, Treasurer's Report]

23 Candidates for licensing as new lawyers include not only recent graduates of JD programs in Canada, but also recent graduates of equivalent programs in other countries, as well as foreign-trained lawyers. For each of these other categories of candidates an initial assessment of eligibility was conducted by the National Committee on Accreditation. Some categories of candidates could seek exemptions from one or both of the parts and under national lawyer mobility arrangements, lawyers from other Canadian provinces could be directly admitted in Ontario. 
the supervision of a lawyer-principal $;{ }^{24}$ and, the third part was a professional responsibility and practice management course undertaken during articling. In addition, post-licensing, new lawyers had to complete eight extra hours of compulsory professional development in their first two years of practice.

This set of requirements had been in place since 2009 and was adopted as a result of a preceding examination of transitional training and articling that had also been prompted by a concern over a shortage of placements. That preceding examination, which was steered by a Licensing and Accreditation Task Force, had raised the possibility of establishing a practical legal training course as an alternative to (or replacement for) articling, but had ultimately proposed only modifications to the then existing articling-centric system, together with measures intended to increase the total number of positions and to connect candidates to them. ${ }^{25}$ In that process, the issue of access to the legal profession received some attention but the issue of access to legal services was largely ignored. ${ }^{26}$

As part of the implementation of the recommendations of the Licensing and Accreditation Task Force, the Law Society undertook measures to generate additional articling positions, especially among sole practitioners and small firms, and in regional and rural areas. These measures were based upon the understanding that these practice environments and geographic areas had disproportionately fewer articling positions available than in larger firms and in major urban centers. The measures included the establishment of an Articling Registry and the rollout of an Articling Survey, intended to identify opportunities for creating more positions and promoting the supports available from the Law Society. As well, the possibility of joint articles among sole practitioners or small firms was promoted as a means of increasing the number of available positions. By 2011, however, although the total number of articling positions had increased, it was not clear that there had been any growth in the sole practice and small firm sector, ${ }^{27}$ and nor was the growth able to keep up with increasing demand for positions. Those circumstances became the impetus for the creation of the Articling Task Force. ${ }^{28}$

24 This could include a private law firm or sole practitioner's office, a government department or agency, a nongovernmental organization or legal clinic or a term as a judicial clerk.

25 Law Society of Upper Canada, Licensing and Accreditation Task Force, Interim Report to Convocation (24 January, 2008) at para $100 \mathrm{~b}$

26 There was a submission from the Law Society's Access to Justice Committee but it took a fairly broad-brush approach to the issues, see Law Society of Upper Canada, Submission of the Access to Justice Committee to the Licensing and Accreditation Task Force (30 May, 2008).

27 For example, there were early indications of interest in joint articles from some 277 firms. But, by the time of the May 2011 report on the annual licensing cycle, by the Law Society's Professional Development and Competence Department, it was reported that not one new joint articling position had been created through this process. See Law Society of Upper Canada, Professional Development and Competence Department Resource and Program Report (May 2011) at 9 online: LSUC $<$ http://www.lsuc.on.ca/WorkArea/DownloadAsset.aspx?id=2147485117> [LSUC, Professional Development (May)].

28 It should be noted that the American legal profession, which has no equivalent of the articling requirement, is also grappling with too few entry-level positions for new lawyers, but at a much greater magnitude than in Canada. This is reportedly having an impact on law school enrolment. See for example, Mark Hansen, "Job Market for Lawyers is Even Bleaker than it Looks" online: (1 April 2013) ABAJournal.com $<$ http://www.abajournal.com/news/article/job_market_for_would-be_lawyers_is_bleaker_than_it_looks_analysis_says/> and Joshua Wright "The Job Market for Lawyers: Side Work on the Rise Amid Continuing Glut of New Grads" online: (10 January, 2014) Forbes.com <http://www.forbes.com/sites/emsi/2014/01/10/the-job-market-for-lawyers-side-workon-the-rise-amid-continuing-glut-of-new-grads/>. 
The move to establish the Articling Task Force was precipitated by a May 2011 report of the Law Society's Professional Development and Competence (PDC) Department on the annual licensing cycle. $^{29}$ The report indicated that $12.1 \%$ of candidates, or 214 of the 1716 people who had by then registered for the 2010-11 cycle, remained unplaced in articling positions at that time. ${ }^{30}$ This was perceived as representing the continuation of a generally upward trend in the unplaced candidate rate. ${ }^{31}$ This increase in rates of unplaced candidates was occurring despite a reported $20 \%$ growth in articling positions between 2008 and $2011^{32}$

After initial meetings during the summer of 2011, the Articling Task Force sought an expansion of its terms of reference, which were approved in September 2011. The original terms of reference had equipped the Articling Task Force to examine the operation and effectiveness of the articling program from the perspective of competency-related principles. ${ }^{33}$ The expansion made it explicit that the Articling Task Force could examine the articling program as a licensing process and, if warranted, could recommend changes not only to articling but, also, to licensing more broadly. ${ }^{34}$ The expanded terms of reference seemed to indicate a broader concern with the fairness of articling as the main component of the lawyer licensing transitional training program. Since the quantity of available articling positions was largely determined by market-based decisions of lawyers in private practice, a shortage of positions might be regarded as an unfair and self-interested barrier to entry to the legal profession that might, in turn, fall afoul of the provincial regulatory framework for fair entry to professions. ${ }^{35}$ This can also be understood as a concern over access to the legal profession.

The Articling Task Force released a Consultation Report in early December 2011 that was followed by a multi-pronged consultation program that ran until the end of March 2012. ${ }^{36}$ The Consultation Report confirmed that the issue of a shortage of articling positions needed to be examined as an issue of fair entry to the profession. ${ }^{37}$ After laying out background information and statistics, including some of the statistics described above, the Consultation Report set out five options for the future of articling and transitional training and also identified ten questions for input. The five options were: 1) the status quo; 2) the status quo but with improvements to quality assurance; 3) shifting from the existing pre-licensing

29 This May report was specifically referenced by the Treasurer's Report tabling the motion to create the Articling Task Force. See Law Society of Upper Canada, Treasurer's Report, supra note 2; LSUC, Professional Development (May), supra note 27.

30 This statistic was first reported in LSUC, Professional Development (May), supra note 27 at 4 . The unplaced candidate rate had fallen to $10 \%$ (174 of 1,748) by the time of the end-of-cycle report of the PDC Department in August 2011.

31 The unplaced candidate rate was reported to be 5.7\% (81 of 1391) in March 2008, 8.3\% (125 of 1,493) in March 2009, and $7.7 \%$ (115 of 1,496) in March 2010. These statistics were included in LSUC, Professional Development (May), supra note 27 at $6-7$.

32 The number of articling positions available was reported to be 1,310 in March 2008 and then 1,553 by March 2011. There are some inconsistencies in figures reported by the Law Society. The figure of 1,553 does not match the number of placed candidates that results from 214 of 1,716 being unplaced, which equals 1,502.

33 LSUC, Treasurer's Report, supra note 2 at 5 (Appendix 1).

34 Law Society of Upper Canada, Articling Task Force, Interim Report to Convocation (22 September 2011) online: LSUC $<\mathrm{http}$ //www.lsuc.on.ca/WorkArea/DownloadAsset.aspx?id=2147485613> [LSUC, Interim Report] at 2.

35 Fair Access to Regulate Professions and Compulsory Trades Act (SO 2006, c 31)

36 Law Society of Upper Canada, Articling Task Force, Consultation Report (9 December 2011) online: LSUC $<$ http://www.lsuc.on.ca/articling-task-force-consultation-report/> [LSUC, Consultation Report].

37 Ibid at 2 and 12. 
system to a post-licensing system, with supports targeted at 'high risk' practice areas; 4) offering a practical legal training course as an alternative to articles, involving either simulated or real-world skills development and application, either during law school or after law school; and, 5) replacing articles with the practical legal training course, so that it became the only pathway to licensing.

The list of 10 questions on which specific input was invited covered a range of matters and two were directed at access to justice issues. One question sought views about "the issue of over-representation of equity-seeking groups in those not able to obtain articling positions" 38 - and therefore raised issues relevant to access to the legal profession. Another question explicitly raised the issue of access to legal services, as follows: "What are your views on introducing a system specifically designed to hire articling students under the supervision of lawyers to provide access to justice to low income Ontarians, equality-seeking groups and regions outside the major metropolitan centres?"39

The consultation program included regional public town-hall meetings with members of the profession and others, as well as dedicated meetings with a range of representative groups and organizations and visits with law faculty students, deans, professors and staff. The Articling Task Force also invited written submissions over this period and eventually received some 125 public submissions. The results of the consultation process were captured in an Interim Report by the Articling Task Force released in May, 2012. ${ }^{40}$ The Articling Task Force's Final Report, ${ }^{41}$ released in October 2012, set out a majority's preference for a combination of options 2) and 4), proposing the Pathways three year pilot project with the LPP, as well as new quality assurance measures for articling, which included a new endof-program in-person formal assessment for all candidates (whether LPP or articling). The LPP was to be an eight month program, equally divided between practice simulation and a work placement. A minority report preferred a variant on options 3) and 4), proposing the abolition of articling and replacing it with a universal two to three month licensing program (of education and exams) and then post-licensing requirements and supports for high-risk practice environments. Consideration of the report began at the October meeting of Convocation, and was then extended to the November meeting, where the majority proposal was approved, together with approval in principle for a levy on the profession to help defray the costs to candidates. ${ }^{42}$

The Law Society moved quickly into the implementation phase, releasing a Request For Proposals (RFP) for provision of the LPP in February 2013. As the LPP RFP process was unfolding, the Law Society had two remaining tasks. The first was to consider in more depth the form and substance of the new end-of-program in-person formal assessment for all candidates. In October 2013 Convocation approved a recommendation of the Professional Development and Competence (PDC) Committee that

Ibid at 31.

Ibid.

40 LSUC, Interim Report, supra note 34. By this time the task force had already been granted an extension of the time to submit a final report to the fall of 2012.

41 Law Society of Upper Canada, Articling Task Force, Final Report "Pathways to the Profession: A Roadmap for the Reform of Lawyer Licensing in Ontario", (25 October 2012 [LSUC, Final Report].

42 The first meeting was October 25 and the second November 22. The matter of the levy was referred to the PDC Committee for recommendation of a specific amount. Ultimately, the PDC Committee recommended a contribution from the Law Society of \$1 million which represented about \$25 per member of the Law Society (of which there are approximately 40,000): see Law Society of Upper Canada, Professional Development \& Competence Committee, Report to Convocation, (21 November 2013) at para 11 [LSUC, Nov 2013 Report]. 
the design and implementation of what it referred to as the 'Final Skills/Culminating Assessments' be deferred for the duration of the pilot project in order to allow the evaluation of the pilot to provide information on the optimal focus and format of any such assessment. ${ }^{43}$ The second remaining task was to develop the plan for evaluating the three year pilot project. In February 2014 the PDC Committee reported to Convocation on a proposed evaluation plan for the Pathways pilot project. ${ }^{44}$ In the meantime, in November 2013, the Law Society had announced that Ryerson University had been chosen as the primary provider of the LPP, with the University of Ottawa as a partner-provider of the Frenchlanguage LPP. Both programs were slated to begin in September 2014. Moreover, the Law Society had also approved an application from the new law school at Lakehead University to integrate satisfaction of the components of the LPP into its 3-year law degree program. ${ }^{45}$

\section{THE LAW SOCIETY ARTICLING TASK FORCE AND ACCESS TO JUSTICE ISSUES AND CONCERNS}

In this Part I will examine four problems with the consideration of access to justice issues in the process and outcomes of the Law Society and Articling Task Force. First, consideration of the Law Society's statutory duty to facilitate access to justice was not included in the terms of reference of the Articling Task Force. This raises concerns about access to legal governance in the sense that the Articling Task Force was not required to give any particular attention or weight to access to justice issues. Second, in terms of access to the legal profession, the decision to establish the LPP as an alternative to articling was regarded by the Articling Task Force and the Law Society as an access improvement, especially as compared to maintaining the status quo. However, this downplayed a number of concerns that were raised about the design and impact of the LPP, including the potentially stigmatizing effect of a so-called 'two-tier' system for professional licensing and the fact that while candidates in the Articling Program would be paid salaries, candidates in the LPP would pay tuition. In addition, although the Law Society sought to ameliorate the financial concerns by equalizing candidate fees across the two pathways, this measure privileged formal over substantive equality. Third, the Articling Task Force solicited input on whether to systematically enlist articling students to meet unmet legal needs in relation to everyday legal problems which seemed to recognize the relevance of access to legal services issues, but it then rejected calls to do so. The Articling Task Force did at least recommend that the work placements put candidates in practice settings aimed at those needs and problems, but this will be unlikely to do much to improve access to legal services. Fourth, despite this recommendation, and despite the new initiative on access to justice, the proposed evaluation of the Pathways pilot does not include consideration of the extent to which either pathway contributes to access to legal services, although specific evaluation of issues relating to access to the legal profession will be undertaken. This again raises concerns about access to legal governance.

43 Law Society of Upper Canada, Professional Development \& Competence Committee, Report to Convocation, (24 October 2013).

44 Law Society of Upper Canada, Professional Development \& Competence Committee, Report to Convocation, (27 February 2014).

45 This was approved at Convocation on November 21, 2013 following a recommendation of the PDC Committee: see, LSUC, supra note 42. 
In following sections of this Part I discuss each of these problems in more detail. I begin and end with problems relating to access to legal governance. In between I address the problems relating to access to the legal profession and access to legal services.

\section{A. Access to Justice and Access to Legal Governance I}

Two dimensions of access to legal governance are of particular concern in this article: first, the extent to which concerns about access to the legal profession and access to legal services were able to be put before the Articling Task Force; and, second, the extent to which the Law Society and Articling Task Force gave sufficient substantive weight to those concerns. The first dimension is largely procedural and is taken up in section 3.D., after I describe and analyze the consideration given to access issues. I address the second dimension, which is more substantive, in this section.

The work of the Articling Task Force, and the Law Society, displayed a reluctance to give sufficient substantive weight to concerns about access to justice. This reluctance is most starkly manifest in the failure to include a direction to consider the Law Society's duty to facilitate access to justice in the mandate of the Articling Task Force. This failure stood in contrast to the explicit reference to the Law Society's duty to ensure professional competence and appeared to contribute to the general side-lining of access to justice issues by the Articling Task Force. ${ }^{46}$ This was particularly evident in the response of the Articling Task Force to submissions that had suggested measures to increase the employment and use of articling students in practise environments that serve so-called everyday legal problems, thereby improving access to legal services. In dismissing these suggestions, the Articling Task Force stated that the Law Society already devoted significant attention to its access to justice mandate, that questions of how to advance that mandate were the focus of its Access to Justice Committee, and that any discussion about applying further resources to enhancing access to justice needed to be "addressed holistically across the Law Society's operations overall.",47

This response was problematic in three ways. First, at the time of the work of the Articling Task Force, there was no overarching holistic process available for considering access to justice across the Law Society's operations, so diverting the issue of improving access to legal services in this way amounted to dismissing it. Second, to identify, in the absence of an overarching process, the Access to Justice Committee as a better forum was to ignore the fact that the Access to Justice Committee had apparently lost interest in publicly engaging the relationship between access to justice and articling. In contrast to its public participation in the 2008 review process, this time around the Access to Justice Committee made only a confidential submission to the Articling Task Force. The existence of the submission was not publicly acknowledged by the Articling Task Force and there is no indication in its Consultation Report or Final Report of the content of the submission, nor of whether the submission had any influence. ${ }^{48}$ This can be contrasted with the actions of the Law Society's Equity Advisory Group

46 The initial terms of reference directed consideration of "the competency-related principles that articling is intended to address, and its effectiveness in addressing those principles." See LSUC, Treasurer's Report supra, note 2 at Appendix 1.

47 LSUC, Final Report, supra note 41 at 67.

48 The existence of a submission by the Access to Justice Committee only came to the attention of the author inadvertently. A representative of the LSUC subsequently explained to the author that confidential submissions by subject-area committees are commonplace. 
and its Aboriginal Working Group, both of which public made submissions on the issue of access to the legal profession. Third, earlier in its own process, the Articling Task Force had been willing to identify access to justice as an issue relevant to its review of articling and, as identified above in the discussion of the Consultation Report, had invited submissions on a specific question relating to that issue. To then refuse to meaningfully consider the issue - knowing that there was no overarching holistic process and knowing that the subject-matter committee was not publicly engaged - was to deliberately orphan the issue of access to legal services within the process.

The lesson to be learned is that in the absence of an overarching holistic process for considering access to justice at the Law Society, a specific obligation to consider the duty to facilitate access to justice should be included in the terms of reference of any policy-making group of the Law Society. In addition, it might need to be made mandatory for the Access to Justice Committee to make public any analysis it conducts of the access to justice dimensions of any issues sent to ad hoc issue-specific policymaking groups established within the Law Society, such as the Articling Task Force - at least where the broader policy-making process includes public engagement and consultation. Without doing either or both of these things, the experience with the Articling Task Force suggests that the statutory duty to facilitate access to justice will not be adequately engaged and, in turn, the substantive dimension of access to legal governance will not be fulfilled.

Alternatively, the Law Society needs to create a holistic process for access to justice issues - which may be what it is doing with the new organizational initiative on access to justice that will be discussed in the final section of this article.

\section{B. Access to Justice as Access to the Legal Profession}

Although the deficiencies in the mandate of the Articling Task Force enabled it to downplay the substantive relevance of access to justice issues, it did engage with the issue of access to the legal profession and regarded its proposal to establish the LPP, alternative to articling as an improvement in access. However, a variety of concerns were raised during the process of developing this proposal and some of these remain live issues. In this section I first address the argument that the articling shortage was more the fault of Ontario law schools than of the legal profession. While this argument was ultimately a red herring, it raised relevant questions about the optimal size of the Ontario legal profession. I then move on to explain the concerns about access to the legal profession that were raised about articling at the time that the Articling Task Force began its work and to review the concerns raised about the LPP proposal and its implementation.

\section{Articling and access to the legal profession: the issues of size}

At numerous points during the work of the Articling Task Force the issues of the size of the legal profession and the size of the annual group of licensing candidates were raised. More specifically it was often suggested that the articling shortage was caused by too large a number of graduates from Ontario law schools, exacerbated by too many Canadian graduates from foreign law schools and too many National Committee on Accreditation (NCA) candidates. ${ }^{49}$ Underlying this suggestion was the idea that

49 NCA candidates are typically non-Canadian foreign-trained lawyers seeking admission to practise in Ontario or other provinces. See e.g., the written submissions (in the form of letters) of Paul Lepsoe (an individual lawyer) and Lerners LPP. The written submissions are available online: LSUC $<$ http://www.lsuc.on.ca/articling-task-force/ $>$ 
the existing size of the legal profession, and its existing capacity for providing transitional training in the form of articling positions, could be regarded as the maximum optimal sizes for meeting ongoing needs for legal services in Ontario. Therefore, it was argued, the mere fact of a shortage in articling positions did not constitute an unfair barrier to entry to the profession. Rather, it represented the legal profession having reached saturation point.

The idea that the Ontario legal profession might have been at optimal size was a potentially relevant consideration for the work of the Articling Task Force because it raised the issue of whether there ought to be some limit on the annual number of places available in transitional training programs. However, the 'blame-the-law-schools' argument was a red herring in that it focused only on a recent period of growth in law school enrolment, without situating the growth in relevant context, and made no real attempt to estimate legal needs or the appropriate size of the legal profession. Numerous submissions pointed to the $25 \%$ growth in law school enrolment in Ontario from 1997 to 2012 and on that basis alone suggested that the articling shortage was the fault of the law schools. ${ }^{50}$ But this growth in law school enrolment was generally in proportion to growth in the general provincial population, growth in the population of undergraduate students at universities in the province and growth in the province's legal profession. ${ }^{51}$ All other things being equal, even if it were assumed that Ontario had a sufficient and fully-employed legal profession in the late 1990s (which would mean ignoring any unmet legal needs at the time), for the per capita supply of lawyers to be maintained (as the proportionate relative growth rates suggest it was), law school enrolment needed to grow at least somewhat in proportion to growth in these other populations. ${ }^{52}$ In addition, even if the growth in law school enrolment was somehow disproportionate, it paled in comparison to growth in foreign-trained lawyers and internationally educated candidates seeking licenses in Ontario. To be precise, and as the Articling Task Force noted, the number of accreditation certificates issued to foreign-trained lawyers rose from 89 in 1998/99 to 709

50 The Consultation Report referred to a growth of $15.5 \%$ between 2001 and 2011 . LSUC, Consultation Report supra note 34 at 10 . A growth rate of around $25 \%$ can be drawn from the figures on enrolment provided in the Final Report, LSUC, Final Report supra note 41 at para 76. Examples of submissions that regarded increased law school enrolment as a cause are: County of Carleton Lawyers Association, Articling Task Force Consultation Report (March 14, 2012) at para 22; and, University of Windsor, Student Articling Working Group, Report Assessing Articling Options, (March 14, 2012) at 9. The written submissions are available online: LSUC $<$ http://www.lsuc.on.ca/articling-task-force/ $>$

51 Statistics Canada reports that the Ontario population was 13.4 million in 2012, which is a growth of $25 \%$ since 1997 , when the provincial population was 10.7 million: see Statistics Canada, "Population" in Canada at a Glance, Catalogue No 12-581-X (Ottawa: Statistics Canada, 2012) online <http://www.statcan.gc.ca/pub/12-581-x/2012000/pop-eng.htm>; and Statistics Canada, The Daily, (15 April 15 1997) online: Statistics Canada <http://www.statcan.gc.ca/dailyquotidien/970415/dq970415-eng.htm>. The Council of Ontario Universities reports that the number of undergraduate students (fulltime equivalent) enrolled at Ontario universities increased from by $19 \%$ in just the period from 2005 $(336,486)$ to 2012 (400,272): see Council of Ontario Universities: Applications and Enrolment, online: COU $<\mathrm{http}$ //www.cou.on.ca/statistics/applications---enrolment.aspx> . The LSUC, Consultation Report, supra note 34, included figures indicating a 34\% increase in full-fee paying members of the Law Society between 2001 and 2011.

52 It should be noted that there is significant variation among developed countries in the per capita numbers of lawyers and few analyses of optimum numbers or studies of how population growth affects prevalence of legal problems (and of what types) or demand for lawyers (and different types of lawyers). Therefore, it may be that a certain magnitude of population growth does not translate into the same magnitude of increase in legal problems or demand for lawyers. 
in 2011/12. ${ }^{53}$ Moreover, the proportion of foreign-trained lawyers and non-Canadian law graduates among Law Society licensing candidates rose from $6.5 \%$ in 2008 to $20 \%$ in $2011 .{ }^{54}$

After some initial equivocation, ${ }^{55}$ the Articling Task Force ultimately did not let itself be side-tracked by the 'blame-the-law-schools' argument but, at the same time, did not grapple with the issue of optimal size in any comprehensive way. It avoided both by taking the position that the number of places available in transitional training could not merely be left to market forces, because those forces could not guarantee a lack of discrimination, unfairness or arbitrariness. Therefore, transitional training places ought to be available for all who qualified for them and the limitations of market forces should be relegated to operating at the point where newly licensed lawyers sought post-licensing positions ${ }^{56}$ In taking this approach however, the Articling Task Force missed an opportunity to properly investigate and address the issues of the sizes of the legal profession and the candidate pool (including the size of law school enrolment), as well as the related issues of the service-capacity of the profession and the magnitude of legal needs. ${ }^{57}$ The furthest it went in that direction was to note recent evidence pointing to unmet civil legal needs in the province (which will be addressed later in this article) and therefore to recognize, in its Final Report, that "[t]here would appear to be room in the profession for more lawyers, albeit perhaps focusing on different and additional areas of practice." ${ }^{, 58}$ The failure to go further may come back to haunt the Law Society as the Pathway pilot project goes on and as decisions need to be made about the future of the LPP. This is because the LPP may not have unlimited capacity, even on a user-pays model, and so it might have been useful to give some guidance on how a reasonable limit on candidate numbers might be determined. This is especially pertinent given that, as the Articling Task Force recognized, the numbers of would-be candidates will continue to rise with the establishment of new domestic law schools, thriving Canadian-law programs at foreign law schools, and increasing NCA applicants.

Whether or not the issue of the size of the legal profession was grappled with, the Articling Task Force had at least recognized a need to engage with the issue of unequal access to the legal profession, whatever its size. It is to that issue that I now turn.

53 LSUC, Final Report, supra note 41 at para 77.

54 Ibid.

55 There were indications in the Consultation Report that the Articling Task Force was tempted to at least partially blame increasing law school enrolment, see LSUC, Consultation Report supra note 34. It should also be noted that there has been a long history of difficult relations between regulators of the legal profession and law schools. For one perspective on this historical tension, see Harry Arthurs "The Tree of Knowledge / The Axe of Power: Gerald Le Dain and the Transformation of Canadian Legal Education” online: (2012) Comparative Research in Law \& Political Economy, Research Paper No. 25/2012 <http://digitalcommons.osgoode.yorku.ca/clpe/22>.

56 There was, however, a brief mention that there may be a limit to the extent to which the Law Society could finance absorption or subsidization of new lawyers based on the annual licensing fees paid by each member of the profession: see LSUC, Final Report, supra note 41 at para 98.c.

57 A recent comparison of the per capita size of the Ontario legal profession with per capita levels in other countries indicates that Ontario is in the middle of the pack and that it is therefore difficult to argue that the province is in any way flooded with lawyers: see Avner Levin \& Asher Alkoby "Barriers to the Profession: Inaction in Ontario, Canada and its Consequences" (2013) 3:3 Oñati Socio-Legal Series 580 at 582.

58 LSUC, Final Report, supra note 41 at para 96.c. See also paragraphs 20 and 21. 


\section{Articling and access to the legal profession: the issue of equality}

For some time the Law Society has acknowledged the need to ensure both that members of historically disadvantaged groups have access to articling positions and that articling does not present a discriminatory barrier to practice. Within the Law Society, those issues have been given attention under the rubric of 'equity and diversity' by internal departments (the Equity and Diversity Program), by subject-matter standing committees (the Equity and Diversity Committee), and by subject-matter projects (for example, the Bicentennial Report and Recommendations on Equity in the Legal Profession and, more recently, the report on Racialization and Gender of Lawyers in Ontario). ${ }^{59}$ Moreover, the PCD Department and Committee have integrated consideration of equity and diversity issues and statistics into their work and reports. Indeed, the placement report of the PCD Committee that underwrote the concern over a general shortage of articling positions also reported an overrepresentation of some historically disadvantaged groups among those who were unplaced.

Historically, the placement rate had typically been lower for self-identifying equality-seeking group members and in recent years this had been a cause for concern at the Law Society. For the purposes of its statistics, the Law Society offers the following categories of equality-seeking groups: Aboriginal, Francophone, LGBT, Disability, and Visible Minority. Unfortunately, after closing the gap between candidates who do and do not self-identify as being a member of one or more of these groups to just under a $2 \%$ difference for the 2008 licensing cycle, the gap increased to $3.4 \%$ for 2009 and increased further to $4 \%$ for the $2010-11$ cycle. ${ }^{60}$ For $2010-11$, the final overall unplaced candidates rate was $10 \%$, but for those candidates who did not self-identify the unplaced rate was only $7.6 \%$. This compared to an unplaced rate of $14 \%$ for those who did self-identify, which included almost $15 \%$ of the visible minority group and $13.6 \%$ of the LGBT group. ${ }^{61}$ It is also worth noting that there had been a steady decline in the proportion of self-identifying equality-seeking group members in the total pool of licensing applicants having dropped from $36.8 \%$ (in 2007) to $26.6 \%$ in 2010 (although this may be more attributable to a decline in self-identification than a decline in participation). ${ }^{62}$

Both the worsening lower placement rate and the declining overall proportion of self-identifying equality-seeking group members were facts that may have indicated worsening discrimination in articling hiring. In its Consultation Report, the Articling Task Force refers to the statistics for the 201011 cycle, but offers no comparison to prior years for equality-seeking group candidates and so gives no indication that this aspect of access to justice may be deteriorating. Nevertheless, as mentioned above, it did include a question seeking input on the issue of over-representation of equity-seeking group members among unplaced candidates. The views on this issue that were included in submissions were in turn reflected in the Interim Report, and were acknowledged, though not exactly addressed, in the Final Report.

59 Law Society of Upper Canada, Bicentennial Report and Recommendations on Equity in the Legal Profession (Toronto: Law Society of Upper Canada, 1997); and Michael Ornstein, Racialization and Gender of Ontario Lawyers (Toronto: Law Society of Upper Canada, 2010).

60 See the annual Placement Reports of the Law Society of Upper Canada available online: LSUC $<$ http://www.lsuc.on.ca/FindingArticles/>.

61 See analysis and sources in Levin \& Alkoby supra note 57 at 583.

62 The Articling Task Force seems to believe it is the former: see LSUC, Final Report, supra note 41 at para 87. 
The submissions on the issue of access to the legal profession identified a number of concerns with the status quo and the proposed options. To begin with, it was generally accepted that a higher unplaced candidate rate among self-identifying members of equality-seeking groups was a matter of concern, ${ }^{63}$ although it was also noted that more and better information was needed to properly understand the situation and its causes. ${ }^{64}$ Moreover, as the Interim Report stated: "The majority of equality-seeking groups reported that the articling program does not serve members of equality-seeking groups well ...[and]... rejected continuing with the status quo." ${ }^{65}$ In its Final Report, the Articling Task Force majority summarized the submissions on this issue in similar fashion, but seemed to fall short of expressly adopting them. ${ }^{66}$ Rather, it spent some time explaining the shortcomings in available data on the issue of the nature and extent of any differential rate of unplaced candidates. ${ }^{67}$ This is no doubt true, but what the Articling Task Force did not mention was that the Law Society itself must at least share the blame for a lack of available data.

At the same time though, a number of submissions noted that offering a practical legal training course as an alternative to articling might not necessarily be the best solution for equality-seeking groups. I now review those concerns.

\section{Access to the legal profession and concerns about the LPP}

The main concerns with establishing a practical legal training course (what is now the LPP) alternative to articling were: a potential lack of opportunity for networking and mentoring; stigmatization and continued discrimination; financial burden; and, inadequacy of provision for minority-language and regionally-located candidates. I will address each of these in turn and identify the shortcomings in the Articling Task Force's handling of each. But one over-arching point is worth making at the outset, specifically, that while these concerns were raised to varying degrees in a number of submissions to the Articling Task Force, each was also given explicit attention in the submission of the Law Society's own Equity Advisory Group (the EAG). The EAG is attached to the Law Society's Equity and Aboriginal Issues Committee and its members include a number of individual lawyers, as well as organizations representing lawyers from various equality-seeking groups. That the Law Society's own advisory group raised concerns that were not satisfactorily addressed by the Articling

63 See in particular African Canadian Legal Clinic, Written Submission of the African Canadian Legal Clinic to the Law Society of Upper Canada Articling Task Force (March 2012), which spoke in terms of the "racialization of the articling shortage" at 3. The written submission is available online: LSUC $<$ http://www.lsuc.on.ca/articling-task-force/>

64 See Toronto Lawyers Association, Response to the Articling Task Force Consultation Report, (15 March 2012) at 4. The written submission is available online: LSUC $<\mathrm{http}$ //www.lsuc.on.ca/articling-task-force/>

65 Law Society of Upper Canada, Summary of Submissions Report in LSUC, Interim Report, supra note 34 at 4.

66 For the ambivalence in the Articling Task Force's position, see LSUC, Final Report, supra note 41 at paras 87-91.

67 The Articling Task Force also noted that apparent differences in rates of unplaced candidates among different equalityseeking groups might be explained by recent increased numbers of candidates from particular groups. For instance, it noted, the increased rate for racialized candidates correlated to increased volumes of NCA candidates and that there was "good reason to suspect that the demographics of unplaced candidates reflects the demographics of the increased sources of candidates." LSUC, Final Report, supra note 41, at para 88. It was then speculated that NCA candidates might suffer disproportionate lack of placement due to a more limited connection to legal practices in Canada - with the implication seemingly being that this is a legitimate basis for disproportionate placement. In the absence of a reference to any actual evidence to support this suspicion and speculation though, such statements would seem merely to illustrate the dangers of policy-making in the absence of proper information. 
Task Force indicates a more systemic problem with equity-related policy-making in general and policymaking/governance on access to the legal profession more particularly.

\section{a. Lack of networking and mentoring}

The first concern expressed about introducing a practical legal training course option was that it may not provide sufficient opportunities for the interpersonal networking and mentoring available in good quality articling experiences - opportunities that were regarded as a particularly important aspect of establishing and developing a legal career for members of equality-seeking groups. ${ }^{68}$ The importance of networking and mentoring as part of transitional training had been recognized by the Articling Task Force in its Consultation Report, where it identified "[i]ntroduction to systemic mentoring" as two of the five goals of transitional training. ${ }^{69}$ The concern of equality-seeking groups over a lack of mentoring was noted in the Interim Report but not explicitly addressed in the Final Report. However, it might be inferred that the Articling Task Force majority saw networking and mentoring needs as a reason to include a work placement component in the LPP proposal. ${ }^{70}$ But at only four months duration, likely unpaid, and with no prospect of ongoing employment, the opportunity for good quality networking and mentoring through the work placement component might be doubted. This doubt is then all the more problematic for members of equality-seeking groups to the extent that they may have special needs for good quality networking and mentoring. ${ }^{71}$

\section{b. Stigmatization and disincentives to alleviating discrimination}

A second concern was that the practical legal training course stream would be stigmatized as a second-best pathway to licensing and would, in turn, stigmatize candidates who undertook it - a stigma that would then fall disproportionately on members of equality-seeking groups, especially if overrepresented in this pathway. ${ }^{72}$ For this reason, some submissions argued that it would be better to make a practical legal training course the sole form of transitional training. ${ }^{73}$ Relatedly, it was also suggested that establishing a practical legal training course as an alternative to articling might give the profession

68 Law Society of Upper Canada, "Equity Advisory Group Submission to the Articling Task Force" (27 February, 2012) at para 26 [LSUC, "EAG Submission"]. The written submission is available online: LSUC

$<\mathrm{http}$ ://www.lsuc.on.ca/articling-task-force/>

69 practitioner" as a goal, and this may include networking.

70 For its part, the minority recommended as part of its proposal that the Law Society organize and administer a provincewide mentoring system for new lawyers in their initial years of practice: see LSUC, Final Report, supra note 41 at para 239-43.

71 This special need was highlighted in the LSUC, "EAG Submission", supra note 68 at paras. 26 and 30 . At the same time, it should be acknowledged that what the LPP might lack in terms of relative quality of mentoring would need to be weighed against what it might offer in terms of relative quality of skills development - although this will depend on the quality of the pedagogy offered.

72 LSUC, "EAG Submission", supra note 68 at paras 24-25.

73 See e.g. ARCH Disability Law Centre, Articling Task Force Consultation, (13 March 2012) at 3 [ARCH, "Submission"]. The written submission is available online: LSUC $<$ http://www.lsuc.on.ca/articling-task-force/ $>$ 
an excuse to stop proactively addressing discrimination in articling hiring. ${ }^{74}$ Indeed, the existence of the LPP could provide cover for increased discrimination in articling hiring since, ultimately, any candidates discriminated against during articling hiring will be able to participate in the LPP and the role of discrimination in driving them to that program may not be transparent.

The concern over stigmatization was acknowledged in both the Interim Report and the Final Report, but in the latter the majority dealt with this concern in somewhat curious ways. The first curiousity was that the only reasons for unequal treatment acknowledged by the Articling Task Force were those that related to where a would-be lawyer was educated, articled or practiced. There was no mention of the possibility that these reasons may incorporate or coincide with unequal treatment or differential impact on discriminatory grounds. This suggests that the Articling Task Force rather missed the point of the concerns expressed by members of equality-seeking groups. Their point was not so much the mere stigma of using a new pathway to licensing that might be perceived as second-rate but, rather, that such stigma would be layered onto, and informed by, the discrimination they already experience in the existing pathway to licensing.

A second curious aspect was how the Articling Task Force sought to placate concerns over stigmatization and other unjustified treatment via the LPP. The Articling Task Force pointed out that since those concerns already existed with respect to articling, they could not be attributed to the mere fact of the introduction of the LPP. ${ }^{75}$ In other words, this seemed to suggest, a new vehicle for potential unjustified differential treatment of equality-seeking group members should be accepted on the basis that unjustified differential treatment already exists in the old vehicle. Perhaps recognizing that this would not count as much comfort, the Articling Task Force went on to state that the Law Society and the legal profession would now need to give this problem "special attention." 76 But the fact that the Law Society, by its own admission, has been unable to satisfactorily prevent existing discriminatory treatment - indeed, does not even have the data it needs to understand the situation - hardly bodes well. This seemed reinforced by a concluding statement that the pilot project 'may' afford an opportunity for the legal profession to challenge such discrimination, rather than to pretend it does not exist. ${ }^{77}$ It could be argued that, if seriously concerned about access to the legal profession, the Law Society must turn this into that opportunity, as part of a broader and renewed effort addressing both pathways and the profession as a whole, especially if the Law Society is right that some are still pretending discrimination does not exist.

\section{c. Financial burden}

A third concern was that any potential improvement in access to the legal profession associated with offering an LPP alternative must be weighed against the potentially detrimental impact of having to pay tuition fees to undertake the LPP. Many submissions noted the general high debt burden of contemporary law graduates and it was also emphasized that members of equality-seeking groups might

\footnotetext{
74 University of Ottawa, Faculty of Law, Ad-hoc Working Group on Articling and Access to Justice, Articling and Access to Justice (March, 2012) at 13. The written submission is available online: LSUC $<\mathrm{http} / / \mathrm{www}$.lsuc.on.ca/articling-taskforce/>

75 LSUC, Final Report, supra note 41 at para 86

76 Ibid.

77 Ibid.
} 
have both higher debt burdens and lower ability to fund further fees from debt or otherwise. ${ }^{78}$ As well, it was pointed out that candidates in the articling pathway would generally be paid a salary thereby creating a differential, financial impact on LPP candidates. ${ }^{79}$

In the Final Report, the majority of the Articling Task Force was generally unsympathetic to the argument that it ought to consider levels of student debt in deciding how to allocate the costs of the changes to lawyer licensing. The precise terms of its response though were somewhat strange. In particular, the Articling Task Force suggested that taking into account, on fairness grounds, the educational debt load of candidates for licensing, might somehow be inconsistent with the Law Society's 'regulatory obligations' and, more specifically, with its primary substantive concern for competence. ${ }^{80}$ But just how this inconsistency could arise was not explained. The only way this can make any sense is if it is based on the assumption that alleviating the cost barrier can only be achieved by sacrificing the quality of transitional training. But no submission contained any argument to that effect and it is difficult to see why such a sacrifice would be the only option. Rather, the point of the submissions was that the Law Society ought to be concerned about the danger that the financial cost associated with undertaking the LPP option might take away with one hand the opportunity that had been given by the other. For licensing candidates unable to afford the tuition fees of the LPP, not to mention the cost of living without a salary, the supposed increased opportunities provided by the LPP to candidates who, in the words of the Articling Task Force, "might otherwise be precluded from qualifying for licensing because of articling placement shortages," 81 would be entirely illusory. As was noted in the Interim Report, in order to avoid this, a number of submissions suggested a variety of strategies, including "scholarships, bursaries, loan forgiveness options, establishment of trusts funds to encourage scholarships, and other potential programs ...". 82 At no point did the Final Report address these options.

Instead, the majority of the Articling Task Force was clear that the reforms it proposed would be selffunding, in the sense that the costs of the changes would be borne by the licensing candidates themselves, although it was at least willing to equalize the costs across the two pathways. More specifically, the majority report estimated that the LPP would cost approximately $\$ 7,000$ per candidate enrolled in that option and that the formal assessment quality assurance measures would cost approximately $\$ 1,320$ for each licensing candidate. Equalized across an estimated 2,000 licensing candidates, with an estimated 400 taking the LPP, the additional costs for all candidates would be approximately $\$ 2,720$, made up of $\$ 1,400$ for the operation of the LPP and $\$ 1320$ for formal assessment measures.

At the October and November Convocations, the issue of financial burden became a significant part of the debate and, as already mentioned, eventually resulted in agreement that the profession would defray some of the cost to licensing candidates through a $\$ 1$ million contribution. This amount was to be applied as a universal discount amounting to approximately a $\$ 500$ reduction to the licensing fees per

\footnotetext{
See e.g. LSUC, “EAG Submission”, supra note 68 at paras 31-37.

See e.g. ARCH. "Submission" supra note 73 at 3.

LSUC, Final Report, supra note 41, at paras 124-5.

LSUC, Final Report, supra note 41, at para 126.

LSUC, Interim Report, supra note 34 at 15.
} 
candidate. ${ }^{83}$ In March 2014, the Law Society formally set the new licensing fee at $\$ 4,710$ - an increase of $\$ 1,900 .{ }^{84}$ Amid protests from students, ${ }^{85}$ the Law Society seemingly committed to developing a limited bursary program or other forms of financial support for students in need. ${ }^{86}$ At the same time, the Law Society also revealed that it would be making a significant one-off contribution to the costs of developing, as opposed to delivering, the LPP. ${ }^{87}$

The Law Society's equalization of the licensing fees and its eventual recognition that the issue of financial barriers to licensing within the new system had to be addressed were relatively positive actions, but there are broader problems with the approach taken that need attention. To begin with, equalization of the licensing fee does not necessarily adequately take account of the fact that many articling candidates have their licensing fees paid for them by their employers. Not only does this mean that the equalization is more apparent than real - since a significant proportion of candidates may not be paying the fees themselves at all - but it also means that a significant portion of the 'universal discount' associated with the $\$ 1$ million is ultimately being directed to employers (i.e. lawyers), not candidates. In addition, applying a discount universally does not allow for consideration of differences in ability to pay among candidates (including, but not limited to, whether they have employers who will pay). The fundamental problem might be seen as a fixation on formal equality, rather than substantive equality. That is, setting the fee at the same level for all candidates, and applying the levy as a universal discount, regardless of differences in who is really paying (candidate or employer) and in who can really afford to pay (candidate v. candidate), means that each strategy privileges formal equality (every candidate is charged the same fee) over substantive equality (every candidate is charged the lowest fee possible, taking into account their ability to pay).

\section{d. Minority language and regional access}

A final concern raised about access to the legal profession was that the Law Society would need to ensure that any practical legal training course would be available in both of Canada's official languages and that it would be equally accessible, in both languages, to candidates throughout the province, particularly for the French-speaking minority-language community candidates. The language concern has been addressed by securing the involvement of the University of Ottawa's French-language common law program in delivering the LPP. However geographic concerns seem to remain, since candidates will

83 Law Society of Upper Canada, Professional Development \& Competence Committee, Report to Convocation, (21 November 2013) at para 16. The universal application of the discount was also referred to by the then Treasurer of the Law Society, Tom Conway, "Presentation on Pathways Change" (delivered at University of Ottawa, Faculty of Law, 19 February 2014) [unpublished, notes on file with author][Conway, "Presentation"].

The figure for the annual licensing fee and the differential is provided in the financial statements of the Law Society for the first quarter of 2014. See Law Society of Upper Canada, "First Quarter Financial Statements" (May 22 2014) Audit \& Finance Committee Report to Convocation 2014 at para 80 [LSUC, Audit].

85 See, for instance, the guest blog by Bhuvana Sankaranarayanan, "Articling and Access to Justice" 2 February 2014 SLAW (blog), online: <http://www.slaw.ca/2014/02/06/articling-fees-and-access-to-justice>.

86 I say 'seemingly' because students in financial need were instructed to contact the Law Society for information on assistance programs, but it was not clear that any such programs had yet been established - this instruction came in the comments of the Treasurer, see Conway, "Presentation" supra note 83.

87 This was also mentioned by the Treasurer in his remarks at the University of Ottawa, see Conway, "Presentation", supra note 83; and is confirmed by the Law Society First Quarter Financial Statements 2014, LSUC, Audit, supra note 84 at para 83 . 
need to attend some portion of the simulated experiential part of the program in-person in either Toronto (English) or Ottawa (French).

In summation, on the issue of access to the legal profession, the Articling Task Force recognized a need to improve and ensure equality and non-discrimination. Moreover, in formulating the Pathways approach and establishing the LPP as an alternative to articling, it offered some means of alleviating the impact of the inequality and discrimination - and arbitrariness - of the articling hiring process and articling position shortages. However, the submissions that spoke to the interests of equality-seeking groups raised a number of concerns about the extent to which the Pathways approach and the design of the LPP may involve inequalities, stigmatization and financial burdens. These concerns were acknowledged by the Articling Task Force, but were not satisfactorily addressed. Two more general aspects of this failure are particularly troubling and also, in my view, reinforce the need for a new approach to access to justice issues at the Law Society. First, each of these concerns were raised at a general level by the Law Society's own EAG (through the Equity and Aboriginal Issues Committee) and it seems particularly troubling that one arm of the Law Society would fail to satisfactorily address concerns raised by another arm. Second, some of the shortcomings were quite fundamental, particularly a lack of available data and an orientation to formal rather than substantive equality. These shortcomings suggest the need for a fundamental re-think of the approach to access to justice issues. Hopefully the Law Society's new access to justice initiative will provide the opportunity for doing so as I will discus below.

Any re-think though will need to look beyond the issue of access to the legal profession to the issue of access to legal services. It is to that issue that I now move.

\section{Access to Justice as Accessible Legal Services}

In this section I consider the extent to which the Articling Task Force engaged with the issue of access to justice as access to legal services. I begin by outlining the issue of access to legal services in relation to the idea of everyday legal problems and note the role that articling plays in steering would-be lawyers away from servicing everyday legal problems. Next, I address the extent to which the five options identified by the Articling Task Force, as well as alternatives to those options, could, or should, utilize licensing candidates to improve access to legal services. Finally, I analyze the decisions made by the Articling Task Force.

\section{Access to legal services: everyday legal problems, unmet legal needs and articling}

The central place now given to access to justice in the mandate of the Law Society reflects the increasing attention given to that issue throughout the Ontario legal community. By the time of the Articling Task Force, numerous leaders, organizations and institutions had identified a 'crisis' of access to justice in Ontario and, indeed, Canada as a whole. ${ }^{88}$

88 For instance: His Excellency the Right Honourable David Johnston, Governor General of Canada,"The Legal Profession in a Smart and Caring Nation: A Vision for 2017" (Address to the Canadian Bar Association, Halifax 14 August 2011) online Governor General: <http://www.gg.ca/document.aspx?id=14195>; The Honourable Thomas Cromwell, Justice of the Supreme Court of Canada entitled his $33^{\text {rd }}$ Viscount Bennett Lecture "Access to Justice: Towards a Collaborative and Strategic Approach (2012) 63 UNBLJ 38; David Scott (co-chairman, Borden Ladner Gervais LLP) addressed access to justice in delivering the William Howard Memorial Lecture at the University of Calgary, see Julius Melnitzer, "David 
Spurred by the growing concerns over access to justice, a few years prior to the establishment of the Articling Task Force, the Law Society was a partner in the Ontario Civil Legal Needs Project (OCLNP), ${ }^{89}$ which attempted a quantitative analysis of the incidence of legal problems, the means people use for resolving (or not) their problems, and the scope of unmet legal needs. A key concept utilized by the OCLNP was the idea of everyday legal problems, which refers to the legal problems that affect people in their personal capacities as part of their everyday lives, including, problems relating to family relationships, wills and powers of attorney, housing, and real estate. The OCLNP found that 35\% of low and middle income Ontarians (with an annual income below $\$ 75,000$ ) had experienced one or more everyday legal problems in the preceding three years and that $60 \%$ of those people who experienced such problems did not have legal assistance. ${ }^{90}$ Women, members of other equality-seeking groups and people in receipt of social assistance were found to be more likely to have experienced these problems and the lower a person's income the less likely they were to have sought legal assistance. ${ }^{91}$ Key reasons for not obtaining, or even seeking, legal assistance, were perceptions that legal services were too costly and eligibility for legal aid too limited. The OCLNP therefore left little doubt about the existence of a crucial unmet need for legal assistance in relation to everyday legal problems or, in other words, about the existence of a significant lack of access to legal services for those problems.

As well as offering a quantification of everyday legal problems and unmet demand for legal assistance, the OCLNP reported on the means by which those problems are typically met. Significantly, its report stated that "from the perspective of low and middle-income Ontarians, one particular type of lawyer is crucial to ensuring access to civil justice: sole practitioners and lawyers practicing in small firms." 92 It was also apparent that an additional important resource are state-funded legal aid and staff

Scott warns of profession's global warming equal" Law Times (13 February 2012) online < http://www.lawtimesnews.com/201202138925/Headline-News/David-Scott-warns-of-professions-global-warmingequal>. The Right Honourable Beverley McLachlin, P.C. Chief Justice of Canada addressed the Council of the Canadian Bar Association at the Canadian Legal Conference, Saturday 16 August 2011, in Halifax, N.S., and referred to Canada's poor rating on access to justice in civil disputes in a recent report of the World Justice Project, online: iPolitics $<$ http://www.ipolitics.ca/2011/08/16/beverley-mclachlin-address-to-the-council-of-the-canadian-bar-association $>/$ and World Justice Project <http://worldjusticeproject.org/sites/default/files/wjproli2011_0.pdf>. Chief Justice McLachlin had also recently reportedly referred to access to justice as a 'basic right' in a speech at Thomson Rivers University, see $<$ http://truomega.ca/2012/02/29/access-to-justice-is-a-basic-right-chief-justice-of-canada-speaks-on-how-our-justicesystem-has-failed-our-middle-class/ $>$.

Law Society of Upper Canada, Ontario Civil Legal Needs Project, Report: Listening to Ontarians (Toronto, May 2010) online $<$ http://www.lsuc.on.ca/media/may3110_oclnreport_final.pdf $>$. [LSUC, Listening to Ontarians] See also the earlier pan-Canadian survey conducted by the Justice Statistics Branch of the Department of Justice: Canada, Department of Justice, The Legal Problems of Everyday Life by Ab Currie (Ottawa: Government of Canada, 2009) online: <http://www.justice.gc.ca/eng/pi/rs/rep-rap/2007/rr07_la1-rr07_aj1/index.html>.

90 LSUC, Listening to Ontarians, ibid at 20-21.

91 Ibid at 30-35.

92 Ibid at 48. On this point the Project cited the following report: Law Society of Upper Canada, Final Report of the Sole Practitioner and Small Firm Task Force (March 2005) online:

$<$ http://www.lsuc.on.ca/media/convmar05solepractitioner.pdf $>$ at 16. As the OCLNP report states, this report was the first comprehensive analysis of sole practitioners and small law firms (defined as firms with fewer than five lawyers) in Ontario. 
lawyers (in private practice, legal clinics or other staff-lawyer offices, such as child protection, the children's lawyer, and the family law office). ${ }^{93}$

The Articling Task Force acknowledged the role that lawyers in small firms, sole practices and legal clinics play in providing access to legal services and also noted the crucial further point that these practice environments were no longer playing a significant role in the articling system. In turn, it recognized that this had "implications not just for the ability of students to find jobs, but potentially for longer term access to justice." "Indeed, at the time, the articling market directed resources in precisely the opposite direction. As the Articling Task Force noted in its Consultation Report, the distribution of articling positions was heavily skewed towards large and medium sized law firms, with small firms, sole practitioners and legal clinics together accounting for only $11 \%$ of places. ${ }^{95}$ While this may represent the maximum number of articling places that these practice environments can afford to support, it does not seem to represent the maximum number of candidates who would be interested in articling in these environments. Although there is no reliable empirical evidence available on the question of candidate articling preferences, anecdotal evidence suggests that far more than $11 \%$ of new graduates have a serious interest in articling, and then lawyering, in practice environments that serve the everyday legal problems of low and middle income Ontarians. ${ }^{96}$ During the Articling Task Force process some students attested to the high demand for these positions and the need to therefore seek articles in other practice environments. $^{97}$

The Articling Task Force mentioned the variety of factors that have contributed to fewer articling positions being offered in the practice environments that serve everyday legal problems. In terms of the private bar component (small firms and sole practitioners), the Articling Task Force noted that it is by no means easy to maintain a viable practice in this sector ${ }^{98}$ and that many practitioners say that they cannot

93 LSUC, Listening to Ontarians, ibid at 24.

94 LSUC, Consultation Report, supra note 36 at 13.

95 For the 2010-11 articling cycle, Law Society reports indicted that the large firms of more than 50 lawyers accounted for $36 \%$ of articling positions. Medium-sized firms (11-50 lawyers) accounted for 25\%. Small firms of 5 to 10 lawyers accounted for $10 \%$. Very small firms (with less than 5 lawyers) accounted for $11 \%$. Governments provided another $10 \%$ of placements and the remainder was provided by judicial clerkships $(6 \%)$, in-house legal departments (1\%) and legal clinics (1\%). See LSUC, Professional Development (May) supra note 27 at 7.

96 See University of Ottawa Common Law Student Society, "Submission to the Law Society of Upper Canada's Articling Task Force" (December 2011) at 1-2, stating that "Many students choose to come to the University of Ottawa specifically to pursue legal careers that do not begin on Bay Street." This written submission is available online: LSUC $<$ http://www.lsuc.on.ca/articling-task-force/>

97 Remarks to this effect were made by student presenters and audience members at a panel discussion on "Articling and Access to Justice: May the (Task) Force Be With Us" held at the University of Ottawa, Faculty of Law, (2 November 2012) (notes on file with author). It should be noted that opting for articling at large firms raises the prospect of young lawyers taking a career path that begins there but then turns in the direction of access to justice lawyering once debt is reduced to a reasonable level or their careers are established. But such statistics as exist on lawyer mobility and change of status suggest that, while many new calls and young lawyers do leave large firms (both voluntarily and involuntarily), only a small proportion move to the practice environments that serve everyday legal problems. See Law Society of Upper Canada, Change of Status Quantitative Study Report (30 April 2010) online: LSUC $<$ http://www.lsuc.on.ca/media/convmay10_change_status_report.pdf $>$.

98 See LSUC, Small Firm at 7. 
afford either the time or the money, or both, needed to employ and train an articling student. ${ }^{99}$ The number of articling placements available in this sector of the legal services market may therefore represent something close to maximum capacity, at least under present economic circumstances. ${ }^{100}$ The so-called 'greying of the bar', which will mean that the senior lawyers who are best placed to provide articling supervision will be leaving practice without a similar number of successors who can fulfill that role, then exacerbates this problem. ${ }^{101}$

In terms of public bar funding for lawyers in legal clinics and other state-funded settings, there may simply be a lack of funding available to expand the number of articling positions offered, even though more positions might be easily justified by demand for legal services. In the legal aid staff lawyer and legal clinic system, there are also disproportionately few articling positions available. Indeed, for many years funding has been so insufficient that only a handful of the over 70 legal clinics are funded to offer an articling position each year. ${ }^{102}$ Alarmingly, some clinics have turned to the desperate tactic of offering unpaid articling positions. ${ }^{103}$

At the same time, the Articling Task Force recognized submissions that attested to a variety of barriers to acceptance of articling positions in everyday legal problems practice environments, including increasing student debt loads that are difficult to service on the relatively low articling salaries available in those practice environments. ${ }^{104}$

The Articling Task Force had reported some of this information in its Consultation Report and, as reflected in the summary of submissions it provided with the Interim Report, had all of this information before it. This information raised the key question for articling in particular, and lawyer licensing more generally, of to what extent they could and should be reformed in order to improve access to justice as access to legal services. There are two dimensions to that question. The first dimension focuses on the process of transitional training itself and asks whether the reforms to lawyer licensing could include measures to increase the use of articling students (or candidates in a practical legal training course) to provide accessible legal services during transitional training. ${ }^{105}$ The second dimension focuses on the

99 See LSUC, Consultation Report, supra note 36 at 13 . At the same time, some will admit that they are also wary about training people who could well end up as competitors for legal business.

100 The Articling Task Force acknowledged that the Law Society and the profession certainly cannot depend upon increased hiring in this sector to solve the general placement shortage issue: see ibid at 13.

101 Ibid.

102 A submission from a legal clinic director stated that Legal Aid Ontario provides funding for only four articling students per year in the community legal clinic system: Community Legal Services Ottawa Centre, Articling Task Force Consultation, (15 March 2013) at 2. This written submission is available online: LSUC

$<$ http://www.lsuc.on.ca/articling-task-force/>

103 Emails from community legal clinics offering such positions are held on file with author.

104 See University of Ottawa Common Law Student Society, supra note 96 at 5. Another factor in adoption, which cannot exactly be characterized as a barrier, is the possible unwillingness of law graduates to relocate to smaller communities to begin their careers. Other factors are no doubt influential, such as the potentially heightened need for interpersonal compatibility between principal and articling student in such small workplace and the risk of magnified detriment to either party if one or the other is not up to the task of being either a principal or trainee-lawyer (see the submission provided Carolyn Gerbac on these types of difficulties, available online: LSUC <http://www.lsuc.on.ca/articling-taskforce $/>$ ).

105 This could include both using candidates to offer legal services for everyday legal problems directly to clients, under supervision, and using candidates to offer legal assistance to lawyers as they offer the direct service. 
post-licensing environment and asks for example whether the reforms to lawyer licensing orienting skills development to lawyering for everyday legal problems could increase the numbers of newly-called lawyers devoting themselves to offering accessible legal services.

These two dimensions of increased provision of accessible legal services - during-licensing and postlicensing - are related, yet also distinct. They are related in the sense that, to increase the direct service offered by licensing candidates, they would have to be immersed or incorporated to some degree in relevant practice environments. This, in turn, might mean that when those candidates become newlycalled lawyers, they are already familiar with the needs of clients with everyday legal problems, and the requirements of meeting their needs thereby more likely to go on to practice in environments that offer accessible legal services, post-licensing. But the two dimensions are distinct in the sense that there will be a limit to the extent to which training in lawyering for everyday legal problems can increase the provision of legal services by newly-called lawyers. The main reason for this limit is that the bulk of the provision of legal services for everyday legal problems occurs in the private market for legal services or, in other words, in the paying market. Therefore, increasing the supply of newly-called lawyers willing and able to offer legal services for everyday legal problems will only be effective if a market for those additional services can be found or created. ${ }^{106}$ Since it is by no means clear that the paying market can be expanded in either of those ways, ${ }^{107}$ in the following sections I will focus on the extent to which the Articling Task Force gave consideration to the idea of harnessing licensing candidates for direct service provision, during licensing. In the next section I turn to a consideration of the extent to which any of the options proposed by the Articling Task Force, as well as alternatives to those options and its eventual decision, could do this.

\section{Reform options and access to legal services}

Without a wholesale re-design to prioritize improving access to justice, it was unlikely that any of the options presented in the Task Force's Consultation Report would produce any significant improvement to access to justice as access to legal services. However, although significant re-designs to that end were suggested, the Articling Task Force rejected them.

\section{a. Articling-centric options and suggestions}

The first two options put forward for consultation by the Articling Task Force were based upon maintaining the status quo articling-centric transitional training program. These could only have improved access to legal services if accompanied by a significant increase or redistribution in articling positions to the practice environments that serve everyday legal problems. A number of submissions to the Articling Task Force suggested or supported a variety of measures targeted at the everyday legal

106 This market could be 'found' if there is a portion of existing unmet legal need that is made up of people who could afford to pay for legal services and can be convinced to do so. Alternatively, this market could be 'created' if there is potential for increased competition within the everyday legal needs market, spurred by the new supply, to lead to lower costs for legal services consumers or to dismantling of other barriers to buying legal services in this area of the market.

The OCLNP survey indicates that cost is not the only factor affecting decisions by people with legal needs not to engage a private market lawyer, so perhaps there is some market that could be found. Moreover, even if it were possible to find or create an additional market, there would still likely be a gap between the bottom of that market and the reach of legal aid (and other programs, such as Pro Bono Law Ontario) - or, in other words, a gap between the private provision of legal services for everyday legal needs and the public and charitable provision of those services. 
problems sector, that could either alleviate the barrier of high student debt or subsidize the costs of hiring, or both. ${ }^{108}$ On the candidate side these measures included; delayed commencement of debt repayment, repayment-geared-to-income, and loan forgiveness, as well as expanding the scope of practice of articling students. On the principal side, the measures included partial license fee-waivers, a levy on the profession to partially subsidize salaries, CPD credits and enhanced hiring and practice supports. These suggestions were noted but not explored by the Articling Task Force. This was perhaps because, given the options ultimately favoured by the Articling Task Force, these measures were not a priority.

Additionally though, there were two proposals for directly funding a significant number of new articling positions in the everyday legal problems sector. In a blog post on the issue of articling reform that preceded the Articling Task Force's Consultation Report, and was subsequently cited in it, Professor Adam Dodek argued that the Law Society and the profession had the capacity to fully or partially fund a significant number of Access to Justice Articling Positions or, in other words, to create a 'legal corps' for access to justice. ${ }^{109}$ Such an initiative would modify the economic and funding constraints of private and public legal service providers engaging everyday legal problems while leaving intact the broader parameters of professional licensing. Thus it would maintain the status quo of lawyer licensing, but add a dedicated access to justice component. Professor Dodek called on the Law Society to fund 200 articling positions, at an annual salary of around $\$ 40,000$, by imposing a $\$ 200$ access to justice levy on the approximately 40,000 lawyers in Ontario. (A variation proposed during the 2008 articling review process would, at least, impose a levy on all lawyers who could act as principals but do not.)

Similarly, the present author put forward the idea of establishing a large-scale civil law legal clinic (or Civil Law Mega-Clinic (CLMC)) aimed at the service delivery gap between the very low-income clients of legal clinics and the higher-income clients of small firms and sole practitioners in the private market. The operation of a CLMC would need to be modeled after the existing legal clinics attached to law schools, which have a pyramid staffing structure (or, for that matter, bigger law firms, which also have a similar pyramid structure), enabling the provision of multiple entry-level positions. ${ }^{110}$ This proposal also called for funding via a levy on the profession as proposed by Dodek, with services provided without fees or on a graduated fee-contribution scale (perhaps with a maximum income eligibility cut-off.)

108 For instance, the submissions of the following lawyers suggested or supported these types of measures: William Grimmett; Shelley McGill; Lori Pope; Rosalind Conway and Paul Calarco. The Carleton County Lawyers Association did likewise. See also the submission of the University of Ottawa, Faculty of Law, Ad-hoc Working Group on Articling and Access to Justice, supra note 74 at 25. These submissions are all available online: LSUC

$<\mathrm{http}: / /$ www.lsuc.on.ca/articling-task-force/>

109 Adam Dodek, “Articling and Access to Justice: An Ontario Legal Corps - Why Not?" (25 October 2011), online: SLAW $<$ http://www.slaw.ca/2011/10/25/articling-and-access-to-justice-an-ontario-legal-corps-why-not/>. Professor Dodek was also a member of the University of Ottawa Faculty of Law Ad-hoc Working Group on Articling and Access to Justice and his suggestion was included in that group's submission as well.

110 The Law Help program of Pro Bono Law Ontario and the recently established Family Law Office could also have served as models. Indeed, in its submission to the Articling Task Force, Pro Bono Law Ontario stated that it had already developed a business plan for a program that sounded similar to this option, see: Pro Bono Law Ontario, "Submission to Articling Task Force" (undated). The written submission is available online: LSUC $<$ http://www.lsuc.on.ca/articlingtask-force/> 
The Task Force addressed Dodek's proposal in its Consultation Report, noting that his suggestion was "ambitious" and "would require significant planning and organization." " Subsequently, there was some support for the 'legal corps' suggestion expressed in submissions to the Articling Task Force, but it seems it was ultimately dismissed without serious consideration. In the Final Report, the Articling Task Force described the amounts of money required, which it estimated at $\$ 9 \mathrm{~m}$ for 200 positions, as "enormous" and that the idea of levying the profession to raise it was not viable. ${ }^{112}$ In questioning the viability of this option, the Articling Task Force seemed to be thinking only in financial terms because while a levy in the order of $\$ 200$ per annum on Law Society members is significant, it is by no means clear that the profession could not afford it. In 2010 the Law Society's revenue was just under $\$ 60$ million. $^{113}$ On the one hand, a levy raising $\$ 9$ million would therefore represent $13 \%$ of the Law Society's general budget, which is certainly significant. On the other hand, during the final decade (1986-96) of the period in which the Law Society had responsibility for operating legal aid in the province, it imposed a legal aid levy that rose from $\$ 175$ to $\$ 266$ per annum. ${ }^{114}$ This levy was cancelled when operation of legal aid was transferred to the newly-created Legal Aid Ontario. Since that time, the Law Society's annual basic fee has increased a few hundred dollars (from $\$ 1,452$ to $\$ 1,866$ ), ${ }^{115}$ but the other main practice expense, the standard errors and omissions insurance premium, has fallen by $\$ 2,000{ }^{116}$ So, it is by no means obvious that the legal profession cannot afford the proposed levy. ${ }^{117}$

As for the CLMC suggestion, the general idea of building delivery of legal services for unmet legal needs into licensing reforms, either through a large-scale clinic or, as will be discussed further below, as part of a practical legal training course, was acknowledged by the Articling Task Force in the Consultation Report and the Interim Report. Indeed, it was noted in the latter that a number of individuals, in written and oral submissions, expressed a willingness to be levied for either approach, ${ }^{118}$ but the Articling Task Force did not expressly address the CLMC option in its Final Report. Presumably, the response given to the suggestion of funding a legal corps was regarded as equally applicable to this option.

111 LSUC, Consultation Report, supra note 37 at 16.

112 LSUC, Final Report, supra note 41 at para 189.

113 Law Society of Upper Canada, 2010 Financial Statements (April 2011) at 8 (General Fund only; does not include any restricted funds), online: LSUC <http://www.lsuc.on.ca/WorkArea/DownloadAsset.aspx?id=2147484609>.

114 Historical data on Law Society dues and fees is collected in Christopher Moore, The Law Society of Upper Canada and Ontario's Lawyers, 1797-1997, (Toronto: University of Toronto Press, 1997). See Table 4 at 349.

115 See the Law Society annual fee amount found online: LSUC <http://www.lsuc.on.ca/For-Lawyers/About-YourLicence/Paying-Your-Law-Society-Fees/ $>$.

116 See Moore, supra note 114, and information on annual premiums provided by the legal profession's self-insurer, LawPRO, online: Lawpro <https://www.lawpro.ca/insurance/private_practice.asp?section=IT>.

117 Having said that, to the extent that viability may be a question of numbers of positions, rather than a funding number, offering even 200 access to justice-oriented articling positions each year is not necessarily a complete longer term solution to the articling shortage. Two hundred positions might take care of the current articling shortage, but demand may soon outstrip even that.

118 See e.g. submissions of Stuart Bailey, Rosalind Conway, Peter Hamiwka, Lori Pope, Joanna Weiss, the Ontario Bar Association and the Hispanic Lawyers Association, available online: LSUC $<$ http://www.lsuc.on.ca/articling-taskforce/> 


\section{b. Options and suggestions for alternatives to articling}

The third option put out for consultation by the Articling Task Force was to abolish the articlingcentric requirements for pre-licensing transitional training and to replace them with post-licensing requirements. In outlining this option, the Consultation Report put special emphasis on the possibility that post-licensing requirements may need to be adapted to, or targeted at, the most challenging and 'risky' (in terms of complaints and negligence claims) sector of the profession, namely, small firm and sole practice. Given the role of this sector in serving everyday legal problems, an access to justice perspective might support the underlying idea that the Law Society ought to be targeting licensing and other resources at this sector. But it is difficult to see how replacing pre-licensing requirements with post-licensing requirements would of-itself increase delivery of legal services in this sector. Although new entrants to the Ontario legal profession would no longer be delayed by the requirement of articling, and could immediately set up practices aimed at everyday legal problems, those practices would only be viable if, as mentioned above, a paying market for their services could be found or created. However, the OCLNP report casts doubt on the idea that there is much untapped ability to pay for legal services in Ontario, at least under the prevailing regulatory framework and practice business models. ${ }^{119}$ Ultimately then, this option offered little potential to improve access to legal services.

The fourth and fifth options put forward by the Articling Task Force revolved around establishing a practical legal training course (PLTC) either as an alternative to articles or as a universal mandatory replacement for articles. On either model, if a PLTC only offered simulated lawyering, and if that included or was geared to training for practice in a small firm or sole practice context, then it may assist in encouraging the entry of more new lawyers into that sector. However, again, since the private market for legal services would still ultimately determine the viability of practice in that sector, the concern would remain that offering a PLTC alternative or replacement would not make any significant contribution to improving access to justice. Indeed, on the replacement model, it might have the detrimental impact of taking away the role that articling students currently play in delivering or supporting accessible legal services.

The PLTC option could only make a meaningful contribution to improving access to justice if it revolved around a significant 'live-practice' component offering legal services for everyday legal problems. Indeed, if the PLTC were so structured, and were implemented as a replacement for articling, it could potentially make a significant contribution to access to legal services. The general idea of making delivery of legal services for unmet legal needs part of any practical legal training course was part of the submission of the Law Society's own Equity Advisory Group. ${ }^{120}$ Also, in a variation on the CLMC proposal, it was suggested that a CLMC could be structured so as to incorporate a PLTC.

With all of this information before it, or available to it, the Articling Task Force opted for the establishment of a PLTC - the LPP - as an alternative to articling, with two components recommended

119 Nevertheless, the minority of the Articling Task Force supported a variant of this option and improving access to legal services was cited as a justification for doing so. Specifically, the minority called for articling to be abolished and replaced with a 2-3 month "comprehensive transitional pre-licensing program" (involving learning and examinations on "legal knowledge and skills, business, professional and ethical issues") [see LSUC, Final Report, supra note 41 at para 202]. According to the minority, doing so would help to facilitate access to justice because it would allow more lawyers to become licensed. However, the minority offered no justification for its apparent belief that the increased supply of lawyers could be matched by a paying demand for their services.

120 LSUC, EAG Submission, supra note 68 at para 29. 
of four months duration each: a "simulated experiential component" and a "work placement."121 While it was hoped that the work placements might be paid, it was expected that they would be predominantly unpaid. The Articling Task Force recognized the possibility of utilizing licensing candidates in the LPP to increase direct delivery of legal services for everyday legal problems via their work placements and set as a goal that "some proportion" of work placements be offered in that sector. ${ }^{122}$ But it did not require that the work placements be so utilized nor explore the suggestion to integrate them into a CLMC. Nevertheless, if the LPP providers meet the goal, then the licensing candidates who occupy these placements will certainly contribute something to improving access to legal services. However, by likely comprising only some portion of the work placements and by lasting only four months, including the time needed to become familiar with the work practices of the work placement environment, the contribution may not be particularly significant. ${ }^{123}$ Certainly, it would be unlikely to match the contribution of a 200-person 10-month articling legal corps or CLMC.

It may be objected that comparing the contribution to access to legal services of the LPP with an articling legal corps or civil law mega-clinic is unfair because the costs of the latter are prohibitive and, therefore, they are not realistic comparisons. But this is by no means clear. Establishing the LPP will cost all licensing candidates an extra $\$ 1,900$ for the $2014-15$ cycle, ${ }^{124}$ which at approximately 2,000 candidates amounts to $\$ 3.8$ million. The profession is itself contributing another $\$ 1$ million. In addition, the Law Society is contributing to the costs of development of the LPP and although there appears to be no publicly available report of what that contribution will ultimately amount to, the Law Society financial statements for the first quarter of 2014 identified an initial contribution of $\$ 900,000$ noting that development would continue until September $2014 .^{125}$ If it is assumed that the establishment of the articling legal corps or a civil law mega-clinic would also require one-off initial development costs of the same magnitude (for, say, acquiring or subsidizing office space and equipment, establishing networked technological infrastructure and developing systematized training and support resources), then that leaves the amount of the annual operating costs of the LPP - roughly $\$ 4.8 \mathrm{~m}$. That amount is not sufficient to pay a 200 -person articling legal corps a $\$ 45,000$ per annum salary, but it could pay them a $\$ 24,000$ salary, which is at least more than minimum wage - and is certainly more than the no-salary provided by the LPP. More funding would be needed to hire the lawyer-principals and other staff needed to provide effective supervision and practice supports for the legal services offered by the articling legal corps or mega-clinic articling students. But perhaps it is conceivable that governmental or philanthropic funders might be convinced to contribute the money to cover those costs - in order to secure a significant increase in access to legal services (and, as some would argue, a corresponding

121 LSUC, Final Report, supra note 41 at para 150.

122 Ibid at para 154.

123 The submission of Sack Goldblatt Mitchell LLP specifically stated that such a short term placement would not be useful in the context of their labour law-oriented practice. See Sack Goldblatt Mitchell LLP "Articling Task Force Consultation Report” (March 30, 2012), available online: LSUC < http://www.lsuc.on.ca/articling-task-force/>

124 The figure of $\$ 1900$ is provided in the financial statements of the Law Society for the first quarter of 2014. See: LSUC, Audit supra note 84 at para 80.

125 Ibid at para 84. 
decrease in the costs of lack of access). ${ }^{126}$ Or, of course, if the levy on the profession were quadrupled to $\$ 100$ per annum, which is not unreasonable in historical terms when compared to the legal aid fee that was once imposed, another $\$ 3 \mathrm{~m}$ would be available for meeting these costs. No doubt other means of raising or re-allocating funds are also possible, with a little effort. The Articling Task Force did not invest any such effort though because, ultimately, in my view, it did not want to give adequate priority to improving access to legal services. In the final section of this article I argue that this reluctance illustrates a failure in the third aspect of access to justice under consideration here, namely, access to legal governance.

\section{Looking Ahead: Access to Justice as Access to Legal Governance II}

The reforms to lawyer-licensing emanating from the work of the Articling Task Force are being treated as a three year pilot project. As described in the preceding sections, the pilot project will not offer as much of an opportunity as it could have to test measures for improving access to justice via the lawyer licensing process. It will be important though to evaluate what it does attempt in that regard, specifically, improving access to the legal profession for members of equality-seeking groups and, to a much lesser extent, improving access to legal services through the proportion of LPP work placements offered in relevant practice environments. In this section I first discuss the shortcomings in the extent to which the emerging evaluation framework will address these issues. In my view, these shortcomings echo deficiencies in access to legal governance in the work of the Articling Task Force, which I then review. Finally, I assess the extent to which the developing Law Society initiative on access to justice might redress these deficiencies.

\section{Pathways Evaluation}

In February 2014, the Convocation approved a multi-phased evaluation model for the Pathways pilot project that covers both the introduction of the LPP and the changes to the articling program. ${ }^{127}$ This model has set the foundation for the development of a variety of evaluation tools and activities to span the three years of the pilot, some of which were to be deployed when it began in September, $2014 .{ }^{128}$

The substantive orientation of the evaluation model echoes the limitations of the Articling Task Force's mandate. Just as an assessment of the relationship between lawyer licensing and access to justice was absent from the mandate of the Articling Task Force, so too is it absent from the statement of the purpose of the pilot project evaluation. ${ }^{129}$ In both instances, lawyer licensing is only about ensuring competence. Consequently, the main orientation of the evaluation is towards assessing the ability of the

126 For work on estimating the costs of justice, and the costs of a lack of access to justice, see the Costs of Justice Project activities, led by the Canadian Forum on Civil Justice, online: <http://www.cfcj-fcjc.org/cost-of-justice>. Canadian Bar Association, Reaching Equal Justice: An Invitation to Envision and Act (Ottawa; Canadian Bar Association, 2013). LSUC, Professional Development (February) supra note 4 at Tab 6.2 (para 5).

As yet, the Law Society has not provided any updates on implementation of the evaluation program, see online: LSUC http://www.lsuc.on.ca/Pathways/> An academic study of the French-language LPP by two professors in the Faculty of Common Law (French Section) at the University of Ottawa (Alain Roussy and Michelle Flaherty) is in progress, as reported in Alain Roussy "Presentation on the Impact of the New LPP on Access to Justice in French in Ontario" (delivered at the Canadian Association of Legal Ethics Annual Conference 2014, Faculty of Law, Western University, 24 October) [unpublished, notes on file with author]

129 LSUC, Professional Development (February) supra note 4 at Tab 6.2 (para 2). 
pathways to produce competent practitioners and to the extent that aspects of access to justice are to be evaluated, this will only be in terms of access to the legal profession.

Nevertheless, the evaluation model does identify a need to gather evidence about, and to assess the impact of the pathways on, access to the legal profession. It is stated that a shared medium-term outcome of the pilot is that each pathway provides "fair, objective and accessible transitional experiential training." $" 130$ In the shorter-term, this is stated to require measuring users perceptions of these aspects of the pathways so that the evaluation can meet an objective of gathering information on "the impact on candidates, including equity-seeking candidates."131 While the specific informationgathering tools are still being developed, and therefore cannot be assessed, the foregoing analysis suggests that attention ought to be paid to the extent and quality of networking and mentoring opportunities in each pathway, the presence of stigmatization or discrimination, the impact of the financial costs (and the adequacy of any ameliorating measures), and the language and geographic reach of the programs.

The evaluation model does not, however, seek to gather any information on the extent to which either pathway contributes to access to legal services and does not appear to make this a relevant consideration in assessing the pilot project. This is despite the fact that the Articling Task Force specifically directed that some proportion of LPP placements be provided in practice environments geared to unmet civil legal needs. This failure reinforces the deficiencies in the substantive dimension of access to legal governance that were evident in the work of the Articling Task Force, to which I now turn.

\section{Access to legal governance and the new access to justice initiative}

Recall, from Part 1 that the expansive conception of access to justice outlined by Macdonald (in a study done for the Law Society) includes an equal right to participation in "every institution where law is debated, created, found, organized, administered, interpreted and applied." ${ }^{\prime 32}$ Macdonald's framework would include law societies and the legal profession among the institutions that need to provide equal rights to participation. Part of this need is captured in the aspect of access to justice that I have here referred to as access to the legal profession. In Macdonald's analysis, access to the legal profession is important not merely as a matter of complying with substantive norms of equality and nondiscrimination in people's pursuit of life and career choices. It is also important for providing historically excluded groups with access to power and authority within the justice system - and, in turn, for bringing the concerns of historically excluded groups into processes of legal policy-making. Additionally, Macdonald argues that those processes also need to be inclusive of and responsive to the broader public and, in particular, to the needs of disadvantaged groups within the public. Putting this in action leads to a requirement that the legal governance processes of institutions such as the Law Society need to aim to provide for the following three dimensions of access to justice for members of equalityseeking and disadvantaged groups. They are: participation in the decision-making body, as members of the decision-making institution; inclusion in decision-making inputs, as members of the public at large and also as members of groups with particular needs; and, recognition in decision-making outputs. The

\footnotetext{
$130 \quad$ Ibid at para 4.

131 Ibid at paras 3 and 4.

132 Macdonald, supra note 11 at 13.
} 
first two of these dimensions are largely procedural, but the third is more substantive in that it requires adequate engagement with, and appropriate weighing of, access to justice concerns and proposals.

Neither the Law Society, in establishing the Articling Task Force, nor the Articling Task Force itself in carrying out its work, erected any specific barriers to the procedural dimensions of access to legal governance. The membership of the Articling Task Force included a lay bencher of the Law Society and their general mandate is to represent the broader public interest to be served by Law Society regulatory activity. ${ }^{133}$ In addition, the Articling Task Force included benchers who are members of equality-seeking groups and who also practiced in diverse settings, including those that serve everyday legal problems. Beyond that, the process of the Articling Task Force allowed for participation by the general public in consultation sessions and in providing submissions. Moreover, the Articling Task Force itself raised some access to justice issues and invited submissions on them. At the same time however, it is not clear whether any members of the general public participated in the consultation sessions - certainly, there were no written submissions received from any individuals or organizations that were not already associated with the legal system.

But the absence of specific procedural barriers did not translate into an adequate substantive engagement with access to justice. As discussed earlier, the failure to ensure fulfillment of the substantive dimension of access to legal governance began with the omission from the mandate of the Articling Task Force of a direction to consider the duty to facilitate access to justice. Compounding this was the failure of the Law Society's own Access to Justice Committee to publicly participate in the process. And while access to justice issues were raised by the Articling Task Force itself, and were commented upon in numerous submissions, including submissions from lawyers and legal entities that are associated with equality-seeking groups and their access to justice needs, the substantive output of the Articling Task Force on relevant aspects of access to justice left much to be desired. Particularly troubling in this respect was the failure to adequately engage the concerns that had been raised by the Law Society's own Equity Advisory Group.

In my view, these shortcomings constituted a failure to ensure the substantive dimension of access to legal governance. In a nutshell, while some discursive space was made available to access to justice issues, the engagement with those issues was insufficient. Just to be clear, this is not to say that the Articling Task Force was not entitled to reach a different conclusion about the reasonableness of the various suggestions for improving access to justice while reforming lawyer licensing. But it is to say that the Articling Task Force did not adequately investigate the access to justice issues, explore the suggestions or explain why it ultimately decided that measures to improve access to justice were not a priority.

In turn, this failure indicates that more needs to be done by the Law Society to ensure access to justice as access to legal governance in relation to tasks such as the one set for the Articling Task Force. Potentially, the Law Society's new access to justice initiative represents some steps in the right direction. The new access to justice initiative seeks to create a framework for reinforcing and integrating access to justice objectives into the Law Society's core business, functions and operational

133 Rabbi Dow Marmur was the lay bencher. 
planning. ${ }^{134}$ This framework will have both internal and external components. Internally, the framework, once developed, is intended to enable the Law Society to re-align resources to enhance its approach to access to justice across its program areas, as well as to enable strategic review, reconsideration and amendment of its rules, regulations, policies and practices "to foster change and innovation and achieve the Law Society's access to justice objectives." ${ }^{335}$ Externally, the framework is intended to position the Law Society as the facilitating entity for a standing forum of partners and stakeholders (the 'Action Group') for collaboration on access to justice issues. ${ }^{136}$

In my view what is particularly significant is that the Law Society by establishing the Action Group with a diverse range of participants seems prepared to share the legal governance space that will be created. In particular, while the Law Society has stated a willingness to support the Action Group through provision of facilitation and infrastructure, it has framed itself as a participant in the Action Group, rather than framing the Action Group as an advisor to the Law Society. In its words, "[t]he Law Society would maintain policy governance oversight of the functioning of The Action Group only to the extent of satisfying itself that its contribution to facilitation and infrastructure remains consistent with the Law Society's access to justice objectives more generally."137

This apparent de-centering of the Law Society's role may be a crucially important aspect of the access to justice initiative. While the Law Society will retain its autonomy for ultimately determining to what extent it will adopt and incorporate positions of the Action Group in its regulatory activities, the Law Society will also share the role of identifying, defining and engaging access to justice issues and priorities with other justice system partners and stakeholders. This has the potential to enable an expansion of the scope of participation, information, ideas and discussion as well as allowing for more genuinely inclusive and collaborative problem-solving. The significance of this approach becomes apparent when it is compared to the approach taken with respect to the Articling Task Force. In terms of the review of articling, the Law Society not only retained decision-making power but also defined the mandate of the Articling Task Force on its own, without broader consultation. The Articling Task Force itself was composed entirely of benchers of the Law Society who were predominantly drawn from a cross-section of the legal profession, but who do not necessarily represent, or provide the views of, a cross-section of the justice system or of society more broadly. Participation was invited in the form of submissions to the Articling Task Force, but it decided for itself how to assess, weigh and balance the various views and what to recommend to the Law Society's governing body (Convocation) - including giving little apparent weight to the submissions of the very Law Society committee charged with providing policy input on relevant issues. Convocation had a lengthy and robust public debate, but it remained a conversation between Benchers. As such, the approach taken with respect to legal

134 LSUC, TAG Working Group Report, supra note 4 at 2. The statutory duty to facilitate access to justice was formally introduced into the Law Society's governing legislation at the same time as its supervisory authority was expanded to include paralegals: see notes 6-9, below, and accompanying discussion in main text..

135 Ibid at 2.

136 In terms of participation, the Working Group Report states an intention to "seek to secure diverse participation ranging from key leaders in governments, courts, academia, and bar and paralegal associations, as well as representatives of Aboriginal, Francophone and equity partners, legal aid and clinics, and other legal and non-legal organizations and groups who play a role in providing access to justice in the province." Ibid at 17.

137 Ibid at 18 
governance on lawyer licensing was relatively open and at least formally consultative, but not in any sense collaborative.

The collaborative approach evident in the external component of the new access to justice initiative is therefore a potentially significant change in direction for the Law Society on legal policy-making concerning access to justice and access to legal governance more broadly. When connected to a more co-coordinated and comprehensive internal approach to access to justice issues, the combination has the potential to yield more satisfactory processes and results for access to justice. At the same time though, realizing this potential may depend upon taking proactive measures to include the needs and perspectives of historically disadvantaged groups, both internally and externally.

The potential for improved access to legal governance, and improved legal policy-making on access to justice comes at an opportune time in relation to the issue of lawyer licensing. The Law Society's development and implementation of the Pathways pilot project evaluation provides an important opportunity for developing and applying the Law Society's new access to justice framework. It is to be hoped that the opportunity is seized.

\section{CONCLUSION}

In this article I have argued that the work of the Law Society, and its Articling Task Force, suffered a number of shortcomings in relation to access to justice. The two most relevant aspects of access to justice were access to the legal profession for would-be lawyers, and access to legal services, for people in Ontario with unmet legal needs for everyday legal problems. The reforms to lawyer licensing needed to improve and ensure access to the legal profession and could have harnessed licensing candidates to increase delivery of legal services for everyday legal problems. The Law Society and the Articling Task Force engaged much more fully with the issue of access to the legal profession than the issue of access to legal services, but came up short on both.

The shortcomings began with the failure to include a responsibility to consider access to justice issues in the mandate of the Articling Task Force even though the Law Society has a statutory duty to facilitate access to justice. Although the Articling Task Force did nevertheless raise access to justice issues, it ultimately hid behind its lack of mandate in side-stepping the issue of access to legal services. In relation to access to the legal profession, the Articling Task Force acknowledged the need to take the issue seriously, but the decisions it reached, and the reasons it gave for them, betrayed a failure to do so. In particular, the Articling Task Force stopped short of committing the Law Society to a renewed effort at addressing discrimination in articling and lawyering, even though the establishment of the LPP may exacerbate already existing stereotyping and stigmatizing. In addition, the Articling Task Force set up a false opposition between financial accessibility and program quality and, insofar as it did attempt to ameliorate financial barriers, relied upon a formal rather than substantive understanding of equality. Moreover, these shortcomings indicated an unwillingness to meaningfully engage with concerns raised by the Equity Advisory Group - the body, internal to the Law Society, that is responsible for providing policy input on this aspect of access to justice. Ultimately, in my analysis, these various shortcomings point to a more fundamental problem with a third aspect of access to justice, namely, access to legal governance. While the process of the Law Society and the Articling Task Force was classically 
consultative, and provided a significant degree of procedural access to legal governance, it needed to be more substantively engaged with access to justice issues and proposals.

Viewed within recent historical context, the shortcomings of the Articling Task Force in relation to access to justice in many ways repeated the shortcomings of the preceding Licensing and Accreditation Task Force. While it may be going too far to say that this illustrates the adage about history repeating itself - first as tragedy and then as farce - it is certainly the case that both episodes represented a missed opportunity to meaningfully consider the relationship between lawyer licensing and access to justice. It is nevertheless an opportune time for reflection on that relationship, as well as on approaches to access to justice policy-making more generally. The lawyer licensing reforms of the Pathways pilot project are to be evaluated over the coming three years, which coincides with the development and implementation of the Law Society's new organizational initiative on access to justice. By bringing these two activities in touch with each other, the Law Society has the opportunity to revisit the relationship between lawyer licensing and access to justice, while also establishing a more effective approach to access to justice policy-making and access to legal governance. 